Liniger Guillaume (Orcid ID: 0000-0001-5380-5425)

Strutton Peter, G. (Orcid ID: 0000-0002-2395-9471)

Moreau Sebastien (Orcid ID: 0000-0001-9446-812X)

\title{
Calving event led to changes in phytoplankton bloom phenology in the Mertz polynya, Antarctica
}

Guillaume Liniger ${ }^{1,2}$, Peter G. Strutton ${ }^{1,2}$, Delphine Lannuzel ${ }^{1}$, Sebastien Moreau ${ }^{3}$

${ }^{1}$ Institute for Marine and Antarctic Studies, University of Tasmania, Hobart, Tasmania, Australia

${ }^{2}$ Australian Research Council Centre of Excellence for Climate Extremes, University of Tasmania, Hobart, Tasmania, Australia

${ }^{3}$ Norwegian Polar Institute, Troms $ø$, Norway

\section{Orcid ID:}

Guillaume Liniger: 0000-0001-5380-5425

Delphine Lannuzel: 0000-0001-6154-1837

Sebastien Moreau: 0000-0001-9446-812X

Peter Strutton: 0000-0002-2395-9471

Corresponding Author: Guillaume Liniger (guillaume.liniger@utas.edu.au).

\section{Key points}

- The calving of the Mertz Glacier tongue led to changes in the phytoplankton bloom and sea-ice phenology in the polynya.

- Our study highlights regional differences in the polynya

- Natural changes in icescape like in the Mertz polynya will soon be accelerated, with consequences for ocean biogeochemistry and ecology.

This article has been accepted for publication and undergone full peer review but has not been through the copyediting, typesetting, pagination and proofreading process which may lead to differences between this version and the Version of Record. Please cite this article as doi: 10.1029/2020JC016387 


\section{Abstract}

Polynyas are subject to variability in winds and ocean circulation and are important sites of ecological productivity. In February 2010, the B09B iceberg collided with the Mertz Glacier Tongue (MGT), calving a $78 \times 40 \mathrm{~km}$ giant iceberg which modified the icescape and primary productivity of the Mertz Polynya. In this study, we use satellite ocean color and sea-ice concentration to investigate the variability, trends and drivers of phytoplankton blooms in the Mertz polynya since 1997. During the bloom, over 21 years, we found: (i) a later ice retreat time, (ii) an increase in sea-ice concentration, (iii) a decrease in open-water period, (iv) a later bloom start and (v) a decrease in bloom duration. Our results suggest that major post-calving changes in the physical characteristics of the polynya, mainly its icescape, are the primary drivers of phytoplankton phenology. More specifically, the MGT calving event resulted in significant seasonal and regional changes, with higher eastern chl-a and mean summer chl-a post-calving. While satellite data are useful to study long-term variability in these inhospitable areas, they only focus on the ocean surface and are obscured by ice and clouds. Additional sub-surface parameters from seal tags, gliders and moorings in the southernmost polar regions would strengthen our comprehension of phytoplankton and physical changes in ocean dynamics that may have far-reaching consequences, from global circulation to carbon export.

\section{Plain language summary}

Polynyas are the most productive areas in the Southern Ocean and play a role in the global oceanic circulation. Evaluating how unexpected and dramatic changes impact biology and chemical cycles in these areas is critical to understand the potential future impact such events may cause on a larger scale. In this paper, we investigated the impact of the calving of a major glacier tongue in the Mertz polynya on the phytoplankton bloom using satellite data. Significant changes happened after the calving event: (i) the bloom duration and open water period time decreased, (ii) the start of the bloom and the retreat of sea-ice were delayed, (iii) the chlorophyll-a (the major phytoplankton pigment which indicates the phytoplankton biomass) and the seaice concentration increased. These findings show that natural changes can impact the 
timing of phytoplankton growth that may have consequences for the rest of the ecosystem, from Antarctic krill to baleen whales.

\section{Introduction}

Coastal polynyas are open water areas in the coastal sea-ice zone (Tamura et al., 2008) maintained by strong katabatic winds or warm water upwelling (Bromwich, 1989). They represent sites of significant sea-ice production, dense water formation and biological activity (Arrigo \& Dijken, 2003; Shadwick et al., 2013; Tamura et al., 2008; Williams \& Bindoff, 2003). They are also the most productive regions of the Southern Ocean (SO) relative to their size (Arrigo et al., 1998). Because of their high productivity, polynyas play an important ecological role for upper trophic levels (Malpress et al., 2017), and significantly contribute to atmospheric carbon dioxide $\left(\mathrm{CO}_{2}\right)$ uptake by the ocean (Arrigo et al., 2015; Marchese et al., 2017; Shadwick et al., 2014). The equivalent of $27 \%$ of the total $\mathrm{SO} \mathrm{CO}_{2}$ sink has been attributed to the large polynya that dominates the Ross Sea continental shelf (Arrigo et al, 2008b).

Coastal polynyas are known as "sea-ice factories" because the sea ice formed near the coast is constantly pushed offshore by katabatic winds. Blooms develop in areas of open waters. For this reason, phytoplankton blooms that develop in polynyas are extremely sensitive to the timing and extent of sea-ice formation and melting events, since these processes determine the length of the production season. In early spring in polynyas, sea-ice decay enhances light penetration, helps to stratify the upper ocean and releases nutrients (particularly iron, $\mathrm{Fe}$ ) all of which sustain phytoplankton growth. Because polynyas are usually replete in macronutrients (Tremblay et al., 2006), blooms may be influenced by water masses with different Fe content. The intrusions of warm and naturally Fe enriched waters (i.e. upper circumpolar deep water, UCDW) that frequently intrude on the continental shelf can fertilise the upper layers and stimulate algal blooms (Hawkings et al., 2014). Alternatively, if the polynya's shelf is devoid of high-salinity shelf waters (HSSW), UCDW from the north may cascade towards ice shelf cavities, accelerate ice shelf melting at the grounding line (Rintoul et al., 2016) and result in the production of Fe-rich subglacial meltwaters, called lce Shelf Water (ISW). ISW may upwell, exit the cavity and further contribute to phytoplankton growth in the polynya in front of the ice shelf and downstream (Gerringa 
et al., 2012; Herraiz-Borreguero et al., 2016; Sherrell et al., 2015). Finally, Fe can be supplied by resuspended sediments caused by buoyancy-driven overturning circulation associated with the melting ice shelves (the "meltwater pump"; St- Laurent et al., 2019) and strong wind-induced mixing. The latter may however disrupt phytoplankton blooms by deepening the surface mixed layer, leading to lower average light exposure for phytoplankton, diluting and diminishing the bloom.

When considering all the coastal polynyas around Antarctica, the Mertz polynya is one of the four regions where Antarctic Bottom Water (AABW) forms, supplying the deep branch of the overturning circulation (Ohshima et al., 2016; Rintoul, 1998; Tamura et al., 2008). In February 2010, the B09B iceberg collided with the Mertz Glacier Tongue (MGT), calving a 78x40 km giant iceberg (Young et al., 2010). The newly calved C28 iceberg and large sections of the B09B grounded in the Adelie Depression, west of the Mertz Glacier, modifying the entire icescape and the activity of the Mertz polynya (Shadwick et al., 2013). Consequences included a 20\% (Tamura et al., 2012) to $\sim 40 \%$ (Ohshima et al., 2016) decrease in sea-ice production in the Mertz polynya after calving. A decrease in the density and volume of dense shelf waters in the Adelie depression was also observed after the calving (Silvano et al., 2016; Snow et al., 2018) where changes in the icescape subsequently impacted properties of AABW. In terms of primary productivity, Shadwick et al. $(2013,2017)$ suggested that net primary production estimated by $\mathrm{O}_{2} / \mathrm{Ar}$ ratio and deficits of dissolved inorganic carbon was twice as high post-calving (2012-2013) compared to pre-calving (2001 and 2008). At this stage, it is not clear how these changes have impacted the phytoplankton bloom phenology and dynamics, which will potentially impact carbon fluxes and nutrition available to upper trophic levels. The present work focuses on the interannual variability, trends and drivers of phytoplankton blooms in the Mertz polynya over the past 21 years, with a focus on contrasting the pre-calving $(1997-2010)$ and postcalving $(2010-2018)$ periods. 


\section{Material and Methods}

\subsection{Study area}

This study focuses on the area $65.5^{\circ} \mathrm{S}-67.5^{\circ} \mathrm{S}$ and $141^{\circ} \mathrm{E}-148^{\circ} \mathrm{E}$ (blue box, Figure 1), which bounds the Mertz polynya. The polynya area was first roughly determined based on literature (Shadwick et al., 2013, 2014, 2017; Silvano et al., 2016; Snow et al., 2018). Subsequently, the limits were refined based on bathymetry, satellite derived ocean color and sea-ice annual climatologies. Detailed bathymetry is shown in figure $1 b$.

\subsection{Remotely sensed surface chlorophyll-a}

While satellite remote sensing is one of the most effective tools available to monitor under-sampled marine systems such as polar oceans (Moutier et al., 2019), this technique faces several obstacles that affect the amount and quality of the data. First, clouds decrease coverage, leading to reduced quality data and increased potential biases (Pereira \& Garcia, 2018; Sirjacobs et al., 2011). Large solar zenith angles also create a significant challenge for atmospheric correction, potentially leading to an underestimation of the in situ chl-a values based on reflectance (Sirjacobs et al., 2011; Wang, 2003). Finally, sea ice influences (1) the coverage of ocean color data, and (2) the reflectance used to calculate chlorophyll (Pereira \& Garcia, 2018). Particles released by sea-ice melt would backscatter more light, increasing the reflectance and modifying the in situ chlorophyll values (Dierssen et al., 2002) This bias is particularly relevant to coastal waters where non-algal and scattering components are significant and atmospheric correction is an issue (Sirjacobs et al., 2011).

Since satellite chl-a has been shown to underestimate in situ chl-a (Clementson et al., 2001; Johnson et al., 2013; Mitchell \& Holm-Hansen, 1991; Pereira \& Garcia, 2018), we used the Johnson et al. (2013) reprocessed SeaWIFS and MODIS-Aqua chl-a L3 mapped 9km 8-day data available from 1997 to 2012 from the Australian Ocean Data Network https://portal.aodn.org.au/. From 2013 to 2018, we downloaded MODIS-Aqua remote sensing reflectance $(\operatorname{Rrs})$ at 443, 490, 510 and $555 \mathrm{~nm}$ from https://oceancolor.gsfc.nasa.gov/ and reprocessed to chlorophyll using the published algorithm (Johnson et al., 2013). SeaWiFS spanned 1997 to 2010 and MODIS-Aqua 
spanned 2002 to 2018. "Bloom years" were created and centered around Austral summer from June $10^{\text {th }}$ year $n$ to June $2^{\text {nd }}$ year $n+1$ (e.g. June 1998 to June 1999, called hereafter summer 1999). The last week was only 5-days for non-leap years.

We tested the difference between MODIS-Aqua and SeaWiFS in the Southern Ocean when co-located data were available and found a mean difference of $-0.046 \pm 0.01 \mathrm{mg}$ $\mathrm{m}^{-3}$ for four arbitrarily chosen 8-day periods in summer (Table 1). We considered this difference to be small enough to allow the creation of a single data set by averaging chl-a concentration for SeaWiFS and MODIS-Aqua when co-located data were available. The merging of both datasets resulted in an increase of spatial coverage from 15 to $25 \%$ on average during the highest chl-a period (supplementary Figure S1). That is, we consider the small error introduced by averaging two sensors to be acceptable, given the increase in spatial and temporal coverage that averaging confers. When combining the 2 datasets, we averaged the common years from 2002 to 2010 , years prior 2002 are only SeaWiFS, while years after 2010 are only MODISAqua.

\subsection{Estimated phenological parameters}

We calculated six bloom phenology metrics for every bloom year at each pixel from 1997 to 2018: bloom start (BS), bloom end, bloom mean (BM), bloom duration (BD), bloom amplitude (BA) and peak time (Marchese et al., 2017, Table 2). The bloom start and end day were defined as the day where chl-a exceeded and then fell below a threshold value, respectively. The bloom duration is the time difference between the bloom end and the bloom start, in days. The highest value during the bloom period is defined as the bloom amplitude $\left(\mathrm{mg} \mathrm{m}^{-3}\right)$, and the day that this occurred is called the peak time. If the number of valid chl-a values for a given pixel for a given year was less than 2, the pixel was removed from the analysis. Where the value of chl-a for a pixel exceeds and falls below the threshold twice, we consider this a double bloom only if there was more than 2 weeks difference between the first bloom and second bloom.

Metrics were calculated using three different methods to determine the chl-a threshold: Siegel et al. (2002), Marchese et al. (2017) and Henson et al. (2018). The three 
methods are briefly described in Table 2 . The three methods were compared by looking at the chl-a climatology of four randomly chosen pixels (supplementary Figure S2). The pixels were picked visually without a defined method nor prior assumptions. A bloom initiation is commonly defined as a marked increase of chl-a (Thomalla et al., 2011). The Henson et al. (2018) method consistently detects the bloom initiation earlier than what we consider a marked increase. Conversely, the Siegel et al. (2002) method estimates a late bloom initiation, a few weeks after the initial increase in chl$a$, and therefore underestimates the bloom duration. We judged the Marchese et al. (2017) method to be the best method for this polynya environment as the increasing chl-a concentration is accurately and consistently captured. Marchese et al. (2017) is also the only method developed for polar environments, which makes it particularly suitable for our dataset.

\subsection{Sea-ice concentration}

Daily satellite-derived sea-ice concentration (SIC) from Nimbus-7 SMMR and SSMI/SSMIS passive microwave data with a $25 \mathrm{~km}$ spatial resolution were obtained from the National Snow and Ice Data Center (NSIDC) http://nsicd.org. Daily data from 1997 to 2018 were turned into 8-day averages to compute sea-ice phenology and to match the chl-a dataset. A pixel was defined as ice-covered if the SIC in that pixel exceeded a threshold. We tested two different thresholds of $35 \%$ coverage ( $\mathrm{Ji}$ et al., 2013; Marchese et al., 2017) and 25\%. No significant difference in the trend of seaice retreat (thereafter called IRT for ice-retreat time) and formation was found between the two thresholds at $95 \%$ confidence. As a result, we used a threshold of $35 \%$. The date when sea-ice concentration first dropped below $35 \%$ was defined as the day of sea-ice retreat for that pixel. Subsequently, the date when sea-ice concentration exceeded $35 \%$ was defined as the day of sea-ice formation. The time between the start of sea-ice retreat and sea-ice formation was defined as the open-water period (OWP). Data were interpolated into the same chl-a data resolution and arranged into the same 8-day segments as described for chl-a. 
8-day data of sea surface temperature (SST) and photosynthetically active radiation (PAR) were obtained from the NASA Ocean Color website (https://oceancolor.gsfc.nasa.gov/). SST data were obtained from the MODIS-Aqua satellite and span September 2002 to December 2018. PAR data were obtained from the SeaWiFS and MODIS-Aqua satellites. As PAR is obtained from satellites, it is not retrievable when the ocean is covered by ice. Hence, PAR is strongly linked to seaice phenology. We found an average difference between SeaWiFS and MODIS-Aqua of 1.97 to 3.37 Einstein $\mathrm{m}^{-2} \mathrm{~d}^{-1}$ (mean difference $2.71 \pm 0.44$ Einstein $\mathrm{m}^{-2} \mathrm{~d}^{-1}$ ) in the SO for 8 randomly-chosen 8-day periods in Austral summer over 5 years. This represents $6.8 \%$ of an average summer PAR value (Figure $6 \mathrm{~g}$ ). As for the chl-a, we considered the difference small enough to merge the two datasets, creating a time series from September 1997 to December 2018. Both SST and PAR have temporal and spatial resolutions of 8 days and $9 \mathrm{~km}$ respectively. Data were arranged into the same 8-day segments as described for chl-a (from June $10^{\text {th }}$ year $n$ to June $2^{\text {nd }}$ year $n+1$ ). For both parameters, each pixel was analysed for trends and annual climatologies during the bloom period.

\subsection{Surface wind}

Directional surface wind data (zonal ( $\mathrm{u}$ ) and meridional $(\mathrm{v})$ vectors) at $10 \mathrm{~m}$ above the ocean surface were obtained from ERA Interim (ECMWF Re-Analysis, http://apps.ecmwf.int/datasets/data/interim-full-moda/levtype=sfc/) and used to retrieve wind speed. The data selected in this study were monthly means from 19972018. The spatial resolution of the data set is approximately $80 \mathrm{~km}$. Analysis of the data showed that the winds almost always blew from southeast to northwest (supplementary Figure S3). Hence, we only used wind speed (WS) to evaluate the contribution of wind to the bloom phenology. 


\subsection{Southern elephant seal data}

We investigated the higher trophic level ecology of polynyas from the perspective of southern elephant seals (Roquet et al., 2014; Treasure et al., 2017) and examined their behaviour in a case study sense, by focusing on one animal with available data in 2009. Data were obtained from the MEOP dataset (http://www.meop.net/). The seal trajectory was compared to daily average surface chl-a concentration.

\subsection{Statistical analysis}

\subsubsection{Interannual variability}

As some of our variables did not meet the assumption of normality, we consistently ran a nonparametric Mann-Kendall test (tau with associated $P$-value, pval) to detect trends in phenological parameters. The Man- Kendall tau indicates the sign and strength of the trend (tau $=0$ meaning no trend), and the $P$-value indicates the significance of the result. If the $P$-value is lower than 0.05 , the trend was considered to be significant.

The links between the inter-annual variability of phytoplankton phenology and environmental factors were explored using a Principal Component Analysis and a Spearman's rank correlation $(p)$ was applied to test the relation between all the metrics.

\subsubsection{Pre- and post-calving}

A nonparametric Mann-Whitney test was performed to determine any significant differences during summer time (December-February) between pre-and post-calving periods for: chl-a concentration, SST, SIC, and WS. We performed the analysis from 1998 to 2010 for pre-calving, and from 2010 to 2018 for post-calving. A nonparametric Mann-Whitney test was also applied to detect any significant regional differences in the mean parameters pre- and post-calving. Mann-Kendall tests (tau with associated $P$-value) were run to detect potential trends during the bloom for the pre- and post- 
calving periods, separately. Every significant difference was identified by a $P$-value at $95 \%$ confidence for both analyses.

\section{Results}

\subsection{Bloom and environmental trends}

The temporal patterns of chl-a, SIC, WS, SST and PAR were investigated to identify potential inter-annual variability in the Mertz polynya over the last 21 years.

Using our whole merged dataset (Table 1), a seasonal increase of chl-a at the end of every calendar year in the spring through summer, is observed (Figure 2a). The mean polynya-averaged chl-a concentration is $1.05 \pm 0.93 \mathrm{mg} \mathrm{m}^{-3}$ with a minimum and maximum of 0.09 and $4.6 \mathrm{mg} \mathrm{m}^{-3}$ respectively (Figure $2 \mathrm{a}$ ). However, the chl-a amplitude varies between years. The lowest values are observed for the summers of 1998, 2001, 2003 and 2004, with a mean polynya-averaged chl-a value of $0.54 \pm 0.05$ $\mathrm{mg} \mathrm{m}^{-3}$ across those years. The highest values occur during the period 2011-2017 with a polynya-averaged chl-a value of $4.5 \mathrm{mg} \mathrm{m}^{-3}$ across those years (Figure 2a). There is a significant and positive trend for the polynya-averaged chl-a over the 21-year period $\left(R^{2}=0.015\right.$, pval $\left.=0.015\right)$. Little interannual variability in SIC is observed from 1997 to 2012 , with an average maximum sea-ice concentration of $82.4 \pm 2.6 \%$ and a minimum of $12.5 \pm 1.8 \%$ (Figure 2b). However, SIC is higher in the 2013, 2014 and 2017 summers (48.7, 39.9 and 43\% respectively), compared to an average minimum summer concentration of $18.8 \pm 17.2 \%$ for the 21 years period (Figure $2 b$ ). Like the chl-a time series, a significant and positive trend in SIC is detected $\left(R^{2}=0.02, p v a l=\right.$ $1.14 \mathrm{e}-04)$.

The mean annual climatology created from 8-day periods, 1997-2018, shows a sharp increase in chl-a concentration from November $25^{\text {th }}$ onwards, reaching a maximum average value of $2.31 \mathrm{mg} \mathrm{m}^{-3}$ in the first week of January (Figure 3). Concentrations remain stable after the peak, from mid-January to the end of February, with an average 
value of $1.63 \pm 0.08 \mathrm{mg} \mathrm{m}^{-3}$ and then decrease until the bloom fades in mid-March. The lowest chl-a concentrations are observed in November and March.

The mean bloom parameter values and standard deviation calculated across all pixels for every Austral summer are summarized in Table 3. A significant positive trend across the 21 years of study is found for the bloom start (tau $=0.46$; pval $=4.1 \mathrm{e}-03$, Figure 4c) with the post-calving years marked by a later bloom start $(2011-2014 ; 2015$ 2016, Table 3). The later BS implies that BD decreases significantly over the study time (tau $=-0.42, \mathrm{pval}=8.6 \mathrm{e}-03$, Figure $4 \mathrm{~b})$. This trend is most pronounced in the post-calving years. On average, BD ranges from a minimum of two weeks (2017/2018) to a maximum of 3 months (2002/2003, Table 3). Despite a strong inter-annual variability and a positive slope, no significant trend is found for BM (not shown) or BA (tau $=0.11, \mathrm{pval}=0.39$, Figure $4 \mathrm{a})$. The highest chl- $\mathrm{a}$ concentrations range from 0.81 to $5 \mathrm{mg} \mathrm{m}^{-3}$ with a mean value of $2.66 \pm 1.25 \mathrm{mg} \mathrm{m}^{-3}$ over the 21 years period (Table 3). The highest chl-a concentration generally appears in the first week of January (day $7 \pm 21$ days), with the earliest peak of concentration occurring the last week of December and the latest at the end of January (Table 3).

All the sea-ice metrics show significant trends on annual average. OWP decreases over time (tau $=-0.55$, pval $=5.2 \mathrm{e}-03$, Figure $4 \mathrm{~d}$ ) whereas SIC and IRT increase (tau $=0.38, \mathrm{pval}=0.017$ and tau $=0.53, \mathrm{pval}=8.03 \mathrm{e}-04$ respectively, Figures $4 \mathrm{f}-\mathrm{i})$. Finally, WS and SST do not show any significant trend across the whole study period (Figures 4h-e), but PAR decreases significantly from 1997 to 2018 (tau $=-0.56$, pval $=6.6 \mathrm{e}$ 04).

\subsection{Relation between bloom phenology and environmental parameters}

Correlations between parameters and their spatial and temporal relations are presented in figures 5 and 6.

The first two modes of our PCA analysis explained $70 \%$ of the phytoplankton bloom dynamics (Figures 5b-c). Most factors (BS, OWP, BD, SIC, PAR, IRT) are distributed on dimension 1 which explains $46.3 \%$ of the variance. Chl-a metrics (BM and $B A$ ) are best represented on dimension 2, which explains $23.7 \%$ of the variance (Figures $5 \mathrm{~b}$ - 
c). SST and WS stand out and are best represented on dimension 3, which explains $11 \%$ of the variance (not shown).

The annual climatology highlights a homogenous BS day across the whole study area (mean start day December $18^{\text {th }}$, Table 3, Figure 6a), except for slightly later onsets in the northeast part of the polynya and near the Ninnis Ice shelf, located east of the MGT. We find significantly negative correlations between BS and OWP, and between BS and PAR ( $\rho=-0.72$ and $\rho=-0.61$ respectively, Figure $5 a)$, meaning that the shorter the open water duration, the later the bloom starts. Even if SST does not show any trend for the period 2002-2018 (tau $=-0.18$; pval $=0.34$, Figure 4e), it is also negatively correlated with BS $(\rho=-0.54$, Figure $5 a)$. Conversely, BS is positively correlated with IRT and SIC ( $\rho=0.7$ and $\rho=0.49$ respectively, Figure 5a), meaning that the longer the sea-ice season and the higher the sea-ice concentration, the later the bloom starts. Finally, an early bloom start translates into a longer bloom duration, as shown by the negative correlation between these two parameters $(\rho=-0.72$, Figure $5 a)$. The bloom lasts longer in the central/western part of the polynya (Figure 6b) where the wind is stronger (Figure 6f). SIC is lower in this part and overall negatively correlated with BD $(\rho=-0.68$, Figures $6 \mathrm{~d}, 5 \mathrm{a})$. BD is positively correlated with OWP $(\rho=0.74$, Figure 5a), but negatively with IRT ( $\rho=-0.62$ and $\rho=-0.68$ respectively). Indeed, the bloom lasts longer during years of higher PAR values, earlier bloom starts, earlier IRT and longer OWP (Figure 5b). Finally, BM and BA are not correlated with BD (Figure 5a).

A strong spatial pattern is distinguishable on the eastern part of the polynya, where the highest values of chl-a are found (Figure $6 \mathrm{c}$ ). This part of the polynya is also characterized by a later BS (Figure 6a), a shorter BD (Figure 6b), and a weaker WS (Figure 6f). The correlation analysis performed for our time series suggests that BA is correlated to BM in the study area ( $\rho=0.98$, Figures $5 a-b)$, but is not correlated with any other potential drivers. The annual climatology reveals higher SIC near the coast and the eastern part of the polynya (Figure $6 \mathrm{~d}$ ). The central/western zone shows the lowest SIC, ranging from 0 to $12 \%$, where we find the highest PAR (Figure $6 \mathrm{~g}$ ). The climatology of PAR shows higher values in the central/western part of the polynya compared to the east (Figure 6g). 
The OWP is negatively correlated with SIC and IRT $(\rho=-0.89$ and $\rho=-0.93$ respectively, Figure 5a), meaning that the earlier the ice retreat, the longer the OWP. SIC and IRT are positively correlated with each other ( $\rho=0.84$, Figure 5a). Years characterized by longer OWP are associated with lower SIC and earlier IRT (Figure 5b). SST appears relatively homogenous over the study area (Figure 6e) albeit slightly higher in the western part of the polynya where SIC is typically lower, and negatively correlated with BS (Figure 5a), meaning that warmer ocean surface is associated with earlier bloom. Finally, WS is surprisingly uncorrelated with all the factors described in this study (Figure 5a). An annual climatology shows stronger winds in the southwestern part of the polynya, while the weakest winds are observed in the north-eastern part (Figure 6f).

\subsection{Impact of the calving on environmental factors}

\subsubsection{Seasonality changes}

The seasonality of environmental factors pre- and post-calving is presented in figure 7. The calving event has a significant impact on two variables in our study. We observe significant differences between pre- and post-calving in mean chl-a and SIC (Figures $7 a-b$, pval < 0.05) during summer (December-February). WS and SST do not show any difference between pre- and post-calving (Figures $7 c-d$, pval $>0.5$ ). Between midNovember and mid-December, all environmental factors show similar trends pre- and post-calving (Figure 7). The main changes take place after mid-December when we simultaneously observe a higher chl-a concentration (Figure 7a), a higher SIC (Figure 7b), and a lower SST (Figure 7c) after the calving event. The chl-a concentration remains stable from that time until the beginning of March, when the SIC increases and SST decreases post-calving compared to pre-calving. For every metric described in the previous section (BS, BA, BD, IRT, SIC, OWP, SST, WS, PAR) none displays a significant trend during the pre-calving nor the post-calving time period (Figure 4, Mann-Kendall test, pval > 0.05, not shown here). 


\subsubsection{Regional changes}

Differences between pre- and post-calving periods for both regions are presented in Table 5 (and supplementary Figures S5-6). A significantly earlier bloom start is observed in the west of the polynya compared to the east prior to the calving event (day $339 \pm 7.8$ days in the west versus day $351 \pm 8.4$ days east, Table 5 , supplementary Figures S5-a, S6-a). The start of the growing season is however significantly delayed in the west post-calving by 23 days on average (Table 5), while no significant change is observed in the east. The bloom start is statistically not different between the west and the east post-calving. When averaging for the whole polynya, the bloom start is significantly delayed post-calving (Table 4).

The west is also characterized by a significantly longer BD pre-calving ( $85 \pm 9$ days in the west, $57 \pm 12$ days in the east, Table 5, supplementary Figure S5-b), which significantly decreases by 40 days on average, post-calving, in this region ( $85 \pm 8.8$ days before against $43.9 \pm 16.3$ days after the calving, Table 5). No major changes are reported in the east. BD is significantly shorter post-calving for the whole polynya (Table 4).

Pre-calving, SIC is twice as low in the west compared to the east (Table 5, supplementary Figure S5-d). SIC increases significantly in the west post-calving by a factor of 2 (17 $\pm 6.6 \%$ post-calving versus $7.6 \pm 10 \%$ pre-calving; Table 5 , supplementary Figure S6-d). No statistical difference is detected in the east pre- and post-calving, nor between west and east after 2010. The average SIC significantly higher for the whole polynya post-calving $(10.65 \pm 2.64 \%$ then $15.83 \pm 5.77 \%$, Table 4). Significantly higher concentrations in the mean and amplitude of chl-a are found in the east compared to the west after the calving (increase by a factor of two, Table 5, supplementary Figure S6-c) while concentrations are statistically the same for the two regions before 2010 (Table 5). No significant changes in chl-a for the whole polynya are observed post-calving (Table 4). Finally, no significant regional, polynya-averaged, and temporal differences in SST are found (Tables 4-5). 


\section{Discussion}

This study investigated the phytoplankton bloom phenology and its drivers in the Mertz polynya over 21 years, with a specific focus on the conditions pre-calving and postcalving using satellite data.

\subsection{Calving impact on regional differences in the polynya}

The annual climatology highlighted some regional differences, including wind patterns that were not discernible at the whole-of-polynya scale. The central and western parts of the polynya exhibited slightly stronger winds, lower mean chl-a concentrations, slightly lower SIC and higher PAR during the bloom. These climatological patterns result from the pre-calving conditions, where the polynya was formed and maintained on the western side of the MGT (Massom et al., 2001). Indeed, as no significant differences were found in BS and BD between east and west after the calving (meaning the BS and BD are homogenous for the whole polynya), the significant sooner bloom start and longer bloom duration we found prior the calving in the west are responsible for these patterns. This also implies that the calving is responsible for the average delay of BS and shorter BD in the whole polynya.

Katabatic winds can be intense and persistent during the bloom season (Périard \& Pettré, 1993). They can deepen the mixed layer, breaking down the earlier summer stratification driven by warming and sea-ice melt. This decreases the ability of phytoplankton to access sufficient light and nutrients (e.g., Fe from sea-ice meltwaters) needed for optimum growth (Ardyna et al., 2017; Arrigo \& Dijken, 2003). This dilution might be compensated for by the observed higher PAR in the western part of the polynya (Figure $6 \mathrm{~g}$ ). Overall, this could explain the weaker but still persistent bloom in this region before the calving. On the other hand, in the eastern part of the polynya, the bloom started later, was shorter, had higher chl-a concentrations, and was associated with weaker winds and slightly higher sea-ice concentration. As for the west, BS and BD patterns are caused by the MGT that was present before 2010. The persistence of the fast ice attached to the tongue could have delayed the growth start in the region and consequently shortened the bloom. 
Stratification is usually required to trigger phytoplankton growth in Antarctic polynyas. Water column stabilization and phytoplankton growth can be attributed to a combination of increased daily solar insolation and decreasing wind stress (Vaillancourt et al., 2003). Weaker winds imply weaker mixing, resulting in stronger stratification. An intrusion of modified circumpolar deep waters (mCDW) has been diagnosed in numerical models of the Mertz Polynya (Aoki et al., 2017; Cougnon et al., 2017), with an increasing presence of $m C D W$ in the eastern part of the Mertz polynya, and a decreasing presence near the Adelie depression after the calving. This reduced the potential for upper-ocean stratification in the Adelie depression. Indeed, the MGT associated with the B9B iceberg and surrounding fast-ice (Tamura et al., 2012) acted as a barrier against sea ice moving westward (Massom et al., 2001) and eastern water masses inflow prior to the calving. The post-calving simulation by Cougnon et al. (2017) showed an intensification of the westward current with warmer $\mathrm{mCDW}$ in the eastern part of the polynya post-calving, as the repositioning of the B9B iceberg in the Adelie Depression no longer provided a barrier to restrict the inflow of warm waters from the east across the Ninnis Bank moving westward. The shorter MGT and a decrease in fast ice build-up to the north and east of the MGT drastically reduced the barrier effect in the polynya (Dragon et al., 2014). Field observations support these model simulations. Shadwick et al. (2014) reported that, because mCDW originates from the Antarctic Circumpolar Deep Water, the water mass that supplies the shelf is not only warm, but also nutrient-rich. Iron is thought to be particularly enriched in the $\mathrm{mCDW}$, as the mCDW comes in contact with the shelf before intruding between $100 \mathrm{~m}$ and 300m in the polynya (Moreau et al., 2019; Silvano et al., 2017). Biomass and net community production doubled in the shallow waters $(<500 \mathrm{~m})$ over the continental shelf in the eastern part of the polynya after calving (Jansen et al., 2018; Shadwick et al., 2017). Our results follow these previous observations. We found a significant increase of mean and maximum concentration of chl- $a$ in the eastern part after the calving, which is significantly different from the west before after the calving. As no difference was found between the two regions prior calving, we conclude the MGT break is responsible for that increase. Associated with warmer water input, increase of basal melt has been reported (Cougnon et al., 2017) in the eastern MGT cavity, potentially releasing trapped iron, making it available for phytoplankton to use. The stratification of the water column from weak winds combined with Fe-rich sea-ice meltwaters at this time of year, as well as Fe supplied from the new eastern mCDW 
inflow, would collectively sustain the stronger bloom observed in the eastern part of the polynya. This is consistent with previous studies which showed that polynyas are not as severely Fe-limited as the rest of the SO (Gerringa et al., 2012; Lannuzel et al., 2007) which act as a factor in favor for the bloom development (Alderkamp et al., 2012).

Antarctic coastal polynyas are known to be influenced by the formation and variability of land-fast ice (fast ice; Fraser et al., 2012; Nihashi \& Ohshima, 2015), which includes sea ice attached to the coast and icebergs grounded near the coast or on shoals (Fraser et al., 2019). Before the calving, the MGT and associated fast ice allowed the creation of the Mertz polynya on the western lee side (Massom et al., 2001). The calving modified the ice dynamics in the region (Nihashi \& Ohshima, 2015). In 2011, B9B migrated across the Adélie Depression and regrounded in Commonwealth Bay with a NNE-ward orientation (Tamura et al., 2012). Changes in iceberg distribution are likely to have an impact via their effect on regional sea-ice extent and fast ice distribution (Massom, 2003). In fact, Antarctic icebergs often ground in water depths of 400-500 m (Massom et al. 2001) and act as anchor points, giving much larger fastice extents. Previous studies reported an increase in fast ice around grounded icebergs after their calving (Banwell et al., 2017; Li et al., 2016; Massom, 2003). Fast ice has also been linked with increases in other sea-ice metrics, such as concentration and thickness (Fraser et al., 2012).

We speculate that changes in fast ice distribution could explain the unusually high SIC in the western part of the polynya post-calving in 2012/2013, 2013/2014 and 2016/2017 (Figure 2b). SIC increased, especially between 140 and $142^{\circ} \mathrm{E}$, where the B9B grounded (Dragon et al., 2014). This is not the case where the MGT calved and further east (Jansen et al., 2018). It was suggested that in this area, the breakup of the sea ice post-calving occurs later in the year. This result is in line with findings from the Ross Sea where sea ice did not break up in spring due to the presence of several large icebergs (Hunke \& Comeau, 2011), whose melting can substantially increase sea-ice concentration and thickness (Merino et al., 2016). This would therefore restrict the bloom to the eastern part of our study zone in these years, where we found significant higher biomass. A similar $50 \%$ to $80 \%$ increase in SIC (relative to the precalving period) was also observed (Campagne et al., 2015; Jansen et al., 2018) in the 
Mertz polynya. Interannual variability in SIC has been reported by Fraser et al. (2019), where they demonstrated that fast ice regulates the size and the total sea-ice production in the Cape Darnley polynya. They also showed that fast ice can reduce sea-ice production when it covers the most ice productive parts of the polynya, consistent with previous studies for the Mertz polynya (Nihashi \& Ohshima, 2015; Tamura et al., 2012).

Overall, this modification of the icescape provoked by the post-calving grounded iceberg reposition could explain: (i) the increase in average SIC, (ii) the average delay of growing season and (iii) the increase in average biomass in the eastern part of the polynya after the calving.

\subsection{Variability of the bloom and its drivers}

We now discuss the results of our multivariate PCA analysis to understand the major drivers of the bloom phenology in the Mertz polynya.

First, wind speed did not show any significant correlation with bloom parameters for the whole polynya (Figure 5a). Instead, we showed that an early bloom start and longer bloom duration were associated with higher PAR, warmer sea surface temperature and earlier sea-ice retreat (Figure 5b). This is because early sea-ice retreat increases light penetration, thereby warming the sea surface. This early sea-ice retreat and warming enhances and shoals the mix layer, which triggers early phytoplankton blooms, as previously observed in the Arctic (Marchese et al. 2017). This is also consistent with previous studies that showed that primary productivity is typically impacted by available light and sea-ice coverage in polynyas (Park et al., 2017; Shadwick et al., 2013, 2017; Vaillancourt et al., 2003).

Second, the results of this PCA highlight that the mean and maximum chl-a concentrations (BM and BA) are not explained by any of the physical factors included in our study, even though they seem to also follow a west-east gradient (Figure 6). Grazing is usually considered an important sink for phytoplankton in polynyas (Arrigo \& Dijken, 2003; Sverdrup, 1953). Photoinhibition and photodamage might also have a negative impact on phytoplankton (Alderkamp et al., 2011, 2012; van de Poll et al., 
2006; Villafañe et al., 2008) although it usually only lowers primary production by up to $10 \%$ in certain areas in the Southern Ocean (Western Antarctic Peninsula, Moreau et al., 2015) Both grazing and photoinhibition were not accounted for in the present study and could explain, in part, the temporal and spatial distribution of the bloom mean and maximum and why they are not explained by environmental parameters. Previous work highlighted the impact of such factors on phytoplankton growth in polynyas (Deibel \& Daly, 2007; Smyth et al., 2017; Yang et al., 2019) where grazing leads to a biomass decrease, shortening the bloom period, and photoinhibition reduces the photosynthetic capacity. Both photoinhibition and grazing should be considered in future studies to fully resolve the drivers of bloom phenology.

The results of the PCA analysis also point out the impact of calving on the phenology and icescape of the Mertz Polynya. Figure $5 \mathrm{c}$ clearly shows the distinction between pre-calving (yellow) and post-calving (blue) years. As shown in this figure, pre-calving years are marked by higher PAR, longer bloom duration and open water period, while post-calving years are characterized by higher SIC, later bloom start and later ice retreat. Modified circulation and icescape leading to these changes have been discussed in the previous section. In pre-calving conditions, the lowest sea-ice concentration led to an earlier sea-ice retreat, meaning longer bloom duration and open waters period (Figures 5b-c), as was previously observed in the Arctic (Ardyna et al., 2014; Arrigo et al., 2008a) and the Peninsula waters of the Southern Ocean (Moreau et al., 2015) where a decrease of sea-ice extent led to an increase in the biological production season. The absence of significant trends in the pre- and postcalving periods for every parameter implies that the changes reported in the section between the two periods are likely due to the calving of the MGT and not a general trend.

Looking at our whole dataset (Figure 2a), we observed the smallest chl-a concentrations before the calving (1998, 2001, 2003 and 2004), and the highest chl-a concentrations after the calving $(2012,2013,2016$ and 2017). This translates to a $20 \%$ increase in chl-a post-calving. This increase was also found in the seasonality of chla (Figure 7a) with significant higher mean summer chl-a concentration post-calving. We attribute this change to the major chl-a increase in the eastern part of the polynya post-calving. On the contrary, once we selected data and reduced our analysis to the 
bloom period only, no significantly higher phytoplankton biomass during the bloom was found (Figure 4a, Table 4), even though it followed a generally increasing trend and despite an earlier ice retreat, a longer open water period and longer bloom duration pre-calving. This result contradicts previous studies in the SO and Arctic open ocean (Del Castillo et al., 2019; Rysgaard et al., 1999) which reported that an increase in chl-a concentration suggests a longer season during which biomass accumulates. In the SO, the difference is likely related to sea-ice coverage. The chl-a increase reported in Del Castillo et al. (2019) was detected during winter and is attributed to changes in stratification and sea surface temperature. In the Arctic, the recycling of nutrients lengthens the growing season (Rysgaard et al., 1999). Similar results have been obtained in the Ross Sea coastal polynya (Tremblay \& Smith, 2007) where the long growing season allows biomass accumulation.

Another reason for the discrepancy of our results could be the method employed to determine the bloom metrics. The threshold criterion has been used by many studies (Cole et al., 2012; Henson et al., 2006, 2009; Racault et al., 2012; Sapiano et al., 2012; Siegel et al., 2002; Thomalla et al., 2011) but has recently been discussed by Behrenfeld and Boss (2018) as rather arbitrary. Other methods such as the critical depth hypothesis (Sverdrup, 1953), the critical turbulence hypothesis (Huisman et al., 1999; Taylor \& Ferrari, 2011), the dilution-recoupling hypothesis (Behrenfeld, 2010; Behrenfeld et al., 2013), the rate of change (Rolinski et al., 2007; Sharples et al., 2006; White et al., 2009) or cumulative biomass (Greve et al., 2005; Mackas et al., 2012) have been proposed to determine bloom metrics, but have their own limitations. Brody et al. (2013) evaluated bloom initiation methods and concluded that the threshold method is the best way to identify the bloom start date, based on the increase of chla concentration, strengthening our choice to apply the Marchese et al. (2017) method. Nevertheless, to enable comparisons between methods, Behrenfeld and Boss (2018) recommended reporting specific rates (division, loss and accumulation) and focussing on phytoplankton carbon biomass, which they define as temporal changes reflecting differences in division and loss rates when mixing depths are constant or shoaling, instead of chl-a as a standard practice when it comes to future phytoplankton studies. The results of our study could slightly change if a different method was applied to determine bloom phenology. The bloom start and end may vary by a few days depending on the method applied, and would therefore affect the bloom duration 
(supplementary Figure S2). This is unlikely to result in a significant change in the bloom time series, as the start, end and duration would either increase or decrease uniformly. The bloom amplitude is independent of the method used to determine bloom phenology.

\subsection{Ecological importance of Antarctic polynyas}

Southern elephant seals are mammals whose habitat is associated with sea-ice (Labrousse et al., 2015) and are known to forage around the Antarctic continental shelf and coastal area (Hindell et al., 2016; Labrousse et al., 2015). In our study case, the seal entered the polynya from the east and followed the high chl-a patch into the central polynya (Figures 8a, 9a). The seal foraged there over the whole month of March while chl-a was high (Figure 9b) and during April, after the bloom had declined (data not shown), before leaving the polynya at the end of the month (Figure 8b). The trajectories followed by this seal strengthens the idea that coastal regions such as polynyas along East Antarctica support large upper trophic level populations from krill to marine mammals (Nicol et al., 2000).

In a warming climate, melting of ice sheets, ice shelves and glaciers will affect the size and shape of polynyas (Arrigo et al., 2012; Barber \& Massom, 2007; McMillan et al., 2014; Paolo et al., 2015; Pritchard et al., 2012; Wouters et al., 2015). This might also lead to a large-scale reduction in Fe stress by releasing glacial Fe, enhancing primary productivity and the spatial extent of blooms (Raiswell et al., 2008). This would alter the habitat for upper trophic levels and potentially support additional export of organic matter to the ocean abyss (Arrigo et al., 2012).

While ocean color satellite data are the optimal dataset for studying trends and changes in phytoplankton phenology (Henson et al., 2018; Johnson et al., 2013), monitoring changes in polynyas could be improved by additional in situ data such as gliders (Kaufman et al., 2014) and seal-derived hydrographic data (conductivitytemperature-depth satellite relay data loggers with fluorometers, Guinet et al., 2012; Roquet et al., 2013) In particular, seal tags allow a much larger spatial and temporal coverage (Roquet et al., 2013) to the under-represented seasons (i.e. fall and winter) and areas such as continental shelf and sea-ice zones (Roquet et al., 2014), which 
include coastal polynyas. Taking in account how challenging polynyas are to sample, in situ data will increase opportunities to monitor bloom initiation more accurately and provide further information such as the vertical distribution of chl-a, subsurface chlorophyll maxima, mixed layer depth, and other physical properties (temperature, density, salinity) which are not detected by satellites.

\section{Summary and Conclusion}

Using satellite data, our study is the first to highlight changes and trends over the past 21 years for a range of physical and biological parameters in the Mertz polynya, with a focal point on pre-calving and post-calving time periods.

During the bloom period across the 21 years of study, we found stable chl-a concentrations in the polynya, despite strong changes observed in the physical environment and bloom phenology: (i) an increase in sea-ice concentration, (ii) a delayed sea-ice retreat, (iii) a decrease in bloom duration, (iv) and shorter open-waters periods. We attribute these trends to the modified icescape of the entire area in the post-calving period. Despite the lack of trend in the maximum chl-a concentration, the calving event did result in significant regional and seasonal changes, with higher mean eastern chl-a and higher mean summer chl-a post-calving.

Given the significant changes in the icescape after the calving (Tamura et al., 2012) and the importance of sea ice in shaping the bloom phenology, our results highlight that major natural changes in the physical characteristics of a polynya, mainly its icescape, are the primary drivers that control its phytoplankton phenology, as found in Li et al. (2016).

In the context of climate change, natural changes in icescape may soon be accelerated, with deep consequences on oceanic biogeochemistry and ecology. These processes will play a significant role in the Mertz polynya system, and other coastal polynyas around Antarctica, with significant consequences for upper trophic levels. 


\section{Acknowledgments}

We would like to thank the ARC Centre of Excellence for Climate Extremes for their support. We are also grateful to Robert Johnson who reprocessed our chlorophyll-a data using his algorithm. We finally thank two anonymous reviewers for their helpful comments and suggestions that helped improve this manuscript.

Satellite data used during this study are available from the NASA ocean color website (http://oceancolor.gsfc.nasa.gov/), the National Snow \& Ice Data Center website (https://nsidc.org/data) and the ERA-Interim website (https://www.ecmwf.int/). Reprocessed chl-a data from Johnson et al. (2013) can be found at https://portal.aodn.org.au/. Seal tag data are accessible from the MEOP website (http://www.meop.net/)

\section{References}

Alderkamp, A.-C., Garcon, V., de Baar, H. J. W., \& Arrigo, K. R. (2011). Short-term photoacclimation effects on photoinhibition of phytoplankton in the Drake Passage (Southern Ocean). Deep Sea Research Part I: Oceanographic Research Papers, 58(9), 943-955. https://doi.org/10.1016/j.dsr.2011.07.001

Alderkamp, A.-C., Mills, M. M., van Dijken, G. L., Laan, P., Thuróczy, C.-E., Gerringa, L. J. A., et al. (2012). Iron from melting glaciers fuels phytoplankton blooms in the Amundsen Sea (Southern Ocean): Phytoplankton characteristics and productivity. Deep Sea Research Part II: Topical Studies in Oceanography, 71-76, 32-48. https://doi.org/10.1016/j.dsr2.2012.03.005

Aoki, S., Kobayashi, R., Rintoul, S. R., Tamura, T., \& Kusahara, K. (2017). Changes in water properties and flow regime on the continental shelf off the Adélie/George V Land coast, East Antarctica, after glacier tongue calving. Journal of Geophysical Research: Oceans, 122(8), 6277-6294. https://doi.org/10.1002/2017JC012925 
Ardyna, M., Babin, M., Gosselin, M., Devred, E., Rainville, L., \& Tremblay, J.-É. (2014). Recent Arctic Ocean sea ice loss triggers novel fall phytoplankton blooms. Geophysical Research Letters, 41(17), 6207-6212. https://doi.org/10.1002/2014GL061047

Ardyna, M., Claustre, H., Sallée, J.-B., D’Ovidio, F., Gentili, B., Dijken, G. L. van., et al. (2017). Delineating environmental control of phytoplankton biomass and phenology in the Southern Ocean: Phytoplankton Dynamics in the SO. Geophysical Research Letters, 44(10), 5016-5024. https://doi.org/10.1002/2016GL072428

Arrigo, K. R., \& Dijken, G. L. van. (2003). Phytoplankton dynamics within 37 Antarctic coastal polynya systems. Journal of Geophysical Research: Oceans, 108(C8). https://doi.org/10.1029/2002JC001739

Arrigo, K. R., Dijken, G. L. van, \& Bushinsky, S. (2008a). Primary production in the Southern Ocean, 1997-2006. Journal of Geophysical Research: Oceans, 113(C8). https://doi.org/10.1029/2007JC004551

Arrigo, K. R., Dijken, G. L. van, \& Long, M. (2008b). Coastal Southern Ocean: A strong anthropogenic $\mathrm{CO}_{2}$ sink. Geophysical Research Letters, 35(21). https://doi.org/10.1029/2008GL035624

Arrigo, K. R., Dijken, G. L. van, \& Strong, A. L. (2015). Environmental controls of marine productivity hot spots around Antarctica. Journal of Geophysical Research: Oceans, 120(8), 5545-5565. https://doi.org/10.1002/2015JC010888

Arrigo, K. R., Lowry, K. E., \& Dijken, G. L. van. (2012). Annual changes in sea ice and phytoplankton in polynyas of the Amundsen Sea, Antarctica. Deep Sea Research Part II: Topical Studies in Oceanography, 71-76, 5-15. https://doi.org/10.1016/j.dsr2.2012.03.006

Arrigo, K. R., Worthen, D., Schnell, A., \& Lizotte, M. P. (1998). Primary production in Southern Ocean waters. Journal of Geophysical Research: Oceans, 103(C8), 15587-15600. https://doi.org/10.1029/98JC00930 
Banwell, A. F., Willis, I. C., Macdonald, G. J., Goodsell, B., Mayer, D. P., Powell, A., \& Macayeal, D. R. (2017). Calving and rifting on the McMurdo Ice Shelf, Antarctica. Annals of Glaciology, 58(75pt1), 78-87. https://doi.org/10.1017/aog.2017.12

Barber, D. G., \& Massom, R. A. (2007). The Role of Sea Ice in Arctic and Antarctic Polynyas. In Elsevier Oceanography Series (Vol. 74, pp. 1-54). Elsevier. https://doi.org/10.1016/S0422-9894(06)74001-6

Behrenfeld, M. J. (2010). Abandoning Sverdrup's Critical Depth Hypothesis on phytoplankton blooms. Ecology, 91(4), 977-989. https://doi.org/10.1890/09-1207.1

Behrenfeld, M. J., \& Boss, E. S. (2018). Student's tutorial on bloom hypotheses in the context of phytoplankton annual cycles. Global Change Biology, 24(1), 55-77. https://doi.org/10.1111/gcb.13858

Behrenfeld, M. J., Doney, S. C., Lima, I., Boss, E. S., \& Siegel, D. A. (2013). Annual cycles of ecological disturbance and recovery underlying the subarctic Atlantic spring plankton bloom. Global Biogeochemical Cycles, 27(2), 526-540. https://doi.org/10.1002/gbc.20050

Brody, S. R., Lozier, M. S., \& Dunne, J. P. (2013). A comparison of methods to determine phytoplankton bloom initiation. Journal of Geophysical Research: Oceans, 118(5), 2345-2357. https://doi.org/10.1002/jgrc.20167

Bromwich, H. D. (1989). Satellite Analyses of Antarctic Katabatic Wind Behaviour. Bulletin America Meteorological Society, 70(7), 738-749. https://doi.org/10.1175/15200477(1989)070<0738:SAOAKW>2.0CO;2

Campagne, P., Crosta, X., Houssais, M. N., Swingedouw, D., Schmidt, S., Martin, A., et al. (2015). Glacial ice and atmospheric forcing on the Mertz Glacier Polynya over the past 250 years. Nature Communications, 6(1), 6642.https://doi.org/10.1038/ncomms7642 Clementson, L. A., Parslow, J. S., Turnbull, A. R., McKenzie, D. C., \& Rathbone, C. E. (2001). Optical properties of waters in the Australasian sector of the Southern Ocean. Journal of Geophysical Research: Oceans, 106(C12), 31611-31625. https://doi.org/10.1029/2000JC000359 
Cole, H., Henson, S., Martin, A., \& Yool, A. (2012). Mind the gap: The impact of missing data on the calculation of phytoplankton phenology metrics. Journal of Geophysical Research: Oceans, 117(C8), n/a-n/a. https://doi.org/10.1029/2012JC008249

Cougnon, E. A., Galton-Fenzi, B. K., Rintoul, S. R., Legrésy, B., Williams, G. D., Fraser, A. D., \& Hunter, J. R. (2017). Regional Changes in Icescape Impact Shelf Circulation and Basal Melting. Geophysical Research Letters, 44(22), 11,519-11,527. https://doi.org/10.1002/2017GL074943

Deibel, D., \& Daly, K. L. (2007). Zooplankton Processes in Arctic and Antarctic Polynyas. In Elsevier Oceanography Series (Vol. 74, pp. 271-322). Elsevier. https://doi.org/10.1016/S0422-9894(06)74009-0

Del Castillo, C. E., Signorini, S. R., Karaköylü, E. M., \& Rivero-Calle, S. (2019). Is the Southern Ocean Getting Greener? Geophysical Research Letters, 2019GL083163. https://doi.org/10.1029/2019GL083163

Dierssen, H. M., Smith, R. C., \& Vernet, M. (2002). Glacial meltwater dynamics in coastal waters west of the Antarctic peninsula. Proceedings of the National Academy of Sciences, 99(4), 1790-1795. https://doi.org/10.1073/pnas.032206999

Dragon, A.-C., Houssais, M.-N., Herbaut, C., \& Charrassin, J.-B. (2014). A note on the intraseasonal variability in an Antarctic polynia: Prior to and after the Mertz Glacier calving. Journal of Marine Systems, 130, 46-55. https://doi.org/10.1016/j.jmarsys.2013.06.006

Fraser, A. D., Massom, R. A., Michael, K. J., Galton-Fenzi, B. K., \& Lieser, J. L. (2012). East Antarctic Landfast Sea Ice Distribution and Variability, 2000-08. Journal of Climate, 25(4), 1137-1156. https://doi.org/10.1175/JCLI-D-10-05032.1

Fraser, A. D., Ohshima, K. I., Nihashi, S., Massom, R. A., Tamura, T., Nakata, K., et al. (2019). Landfast ice controls on sea-ice production in the Cape Darnley Polynya: A case study. $\begin{array}{llll}\text { Remote Sensing of } & 111315 .\end{array}$ https://doi.org/10.1016/j.rse.2019.111315 
Gerringa, L. J. A., Alderkamp, A.-C., Laan, P., Thuróczy, C.-E., De Baar, H. J. W., Mills, M. M., et al. (2012). Iron from melting glaciers fuels the phytoplankton blooms in Amundsen Sea (Southern Ocean): Iron biogeochemistry. Deep Sea Research Part II: Topical Studies in Oceanography, 71-76, 16-31. https://doi.org/10.1016/j.dsr2.2012.03.007

Greve, W., Prinage, S., Zidowitz, H., Nast, J., \& Reiners, F. (2005). On the phenology of North Sea ichthyoplankton. ICES Journal of Marine Science, 62(7), 1216-1223. https://doi.org/10.1016/j.icesjms.2005.03.011

Guinet, C., Xing, X., Walker, E., Monestiez, P., Marchand, S., Picard, B., et al. (2012). Calibration procedures and first data set of Southern Ocean chlorophyll a profiles collected by elephant seal equipped with a newly developed CTD-fluorescence tags. Earth System Science Data Discussions, 5(2), 853-891. https://doi.org/10.5194/essdd-5-853-2012

Hawkings, J. R., Wadham, J. L., Tranter, M., Raiswell, R., Benning, L. G., Statham, P. J., et al. (2014). Ice sheets as a significant source of highly reactive nanoparticulate iron to the oceans. Nature Communications, 5(1), 3929. https://doi.org/10.1038/ncomms4929

Henson, S. A., Cole, H. S., Hopkins, J., Martin, A. P., \& Yool, A. (2018). Detection of climate change-driven trends in phytoplankton phenology. Global Change Biology, 24(1), e101-e111. https://doi.org/10.1111/gcb.13886

Henson, S. A., Dunne, J. P., \& Sarmiento, J. L. (2009). Decadal variability in North Atlantic phytoplankton blooms. Journal of Geophysical Research, 114(C4), C04013. https://doi.org/10.1029/2008JC005139

Henson, S. A., Robinson, I., Allen, J. T., \& Waniek, J. J. (2006). Effect of meteorological conditions on interannual variability in timing and magnitude of the spring bloom in the Irminger Basin, North Atlantic. Deep Sea Research Part I: Oceanographic Research Papers, 53(10), 1601-1615. https://doi.org/10.1016/j.dsr.2006.07.009

Herraiz-Borreguero, L., Lannuzel, D., van der Merwe, P., Treverrow, A., \& Pedro, J. B. (2016). Large flux of iron from the Amery Ice Shelf marine ice to Prydz Bay, East Antarctica. 
Journal of Geophysical Research: Oceans, 121(8), 6009-6020. https://doi.org/10.1002/2016JC011687

Hindell, M. A., McMahon, C. R., Bester, M. N., Boehme, L., Costa, D., Fedak, M. A., et al. (2016). Circumpolar habitat use in the southern elephant seal: implications for foraging success and population trajectories. Ecosphere, 7(5), e01213. https://doi.org/10.1002/ecs2.1213

Huisman, J., van Oostveen, P., \& Weissing, F. J. (1999). Critical depth and critical turbulence: Two different mechanisms for the development of phytoplankton blooms. Limnology and Oceanography, 44(7), 1781-1787. https://doi.org/10.4319/lo.1999.44.7.1781

Hunke, E. C., \& Comeau, D. (2011). Sea ice and iceberg dynamic interaction. Journal of Geophysical Research, 116(C5), C05008. https://doi.org/10.1029/2010JC006588 Jansen, J., Hill, N. A., Dunstan, P. K., Cougnon, E. A., Galton-Fenzi, B. K., \& Johnson, C. R. (2018). Mapping Antarctic Suspension Feeder Abundances and Seafloor FoodAvailability, and Modeling Their Change After a Major Glacier Calving. Frontiers in Ecology and Evolution, 6, 94. https://doi.org/10.3389/fevo.2018.00094

Ji, R., Jin, M., \& Varpe, $\varnothing$. (2013). Sea ice phenology and timing of primary production pulses in the Arctic Ocean. Global Change Biology, 19(3), 734-741. https://doi.org/10.1111/gcb.12074

Johnson, R., Strutton, P. G., Wright, S. W., McMinn, A., \& Meiners, K. M. (2013). Three improved satellite chlorophyll algorithms for the Southern Ocean. Journal of Geophysical Research: Oceans, 118(7), 3694-3703. https://doi.org/10.1002/jgrc.20270

Kaufman, D. E., Friedrichs, M. A. M., Smith, W. O., Queste, B. Y., \& Heywood, K. J. (2014). Biogeochemical variability in the southern Ross Sea as observed by a glider deployment. Deep Sea Research Part I: Oceanographic Research Papers, 92, 93106. https://doi.org/10.1016/j.dsr.2014.06.011

Labrousse, S., Vacquié-Garcia, J., Heerah, K., Guinet, C., Sallée, J.-B., Authier, M., et al. (2015). Winter use of sea ice and ocean water mass habitat by southern elephant 
seals: The length and breadth of the mystery. Progress in Oceanography, 137, 52-68. https://doi.org/10.1016/j.pocean.2015.05.023

Lannuzel, D., Schoemann, V., de Jong, J., Tison, J.-L., \& Chou, L. (2007). Distribution and biogeochemical behaviour of iron in the East Antarctic sea ice. Marine Chemistry, 106(1), 18-32. https://doi.org/10.1016/j.marchem.2006.06.010

Li, T., Ding, Y., Zhao, T., \& Cheng, X. (2016). Iceberg calving from the Antarctic Nansen Ice Shelf in April 2016 and its local impact. Science Bulletin, 61(15), 1157-1159. https://doi.org/10.1007/s11434-016-1124-9

Li, Y., Ji, R., Jin, M., \& Stroeve, J. (2016). Synchronicity between Ice Retreat and Phytoplankton Bloom in Circum-Antarctic Polynyas. Geophysical Research Letters, 2086-2093. https://doi.org/10.1002/2016GL067937

Mackas, D. L., Greve, W., Edwards, M., Chiba, S., Tadokoro, K., Eloire, D., et al. (2012). Changing zooplankton seasonality in a changing ocean: Comparing time series of zooplankton phenology. Progress in Oceanography, 97-100, 31-62. https://doi.org/10.1016/j.pocean.2011.11.005

Malpress, V., Bestley, S., Corney, S., Welsford, D., Labrousse, S., Sumner, M., \& Hindell, M. (2017). Bio-physical characterisation of polynyas as a key foraging habitat for juvenile male southern elephant seals (Mirounga leonina) in Prydz Bay, East Antarctica. PLOS ONE, 12(9), e0184536. https://doi.org/10.1371/journal.pone.0184536

Marchese, C., Albouy, C., Tremblay, J.-É., Dumont, D., D’Ortenzio, F., Vissault, S., \& Bélanger, S. (2017). Changes in phytoplankton bloom phenology over the North Water (NOW) polynya: a response to changing environmental conditions. Polar Biology, 40(9), 1721-1737. https://doi.org/10.1007/s00300-017-2095-2

Massom, R. A., Hill, K. L., Lytle, V. I., Worby, A. P., Paget, M. J., \& Allison, I. (2001). Effects of regional fast-ice and iceberg distributions on the behaviour of the Mertz Glacier polynya, East Antarctica. Annals of Glaciology, 33, 391-398. https://doi.org/10.3189/172756401781818518 
Massom, R. A. (2003). Recent iceberg calving events in the Ninnis Glacier region, East Antarctica.

Antarctic

Science,

15(2),

303-313.

https://doi.org/10.1017/S0954102003001299

McMillan, M., Shepherd, A., Sundal, A., Briggs, K., Muir, A., Ridout, A., et al. (2014). Increased ice losses from Antarctica detected by CryoSat-2. Geophysical Research Letters, 41(11), 3899-3905. https://doi.org/10.1002/2014GL060111

Merino, N., Le Sommer, J., Durand, G., Jourdain, N. C., Madec, G., Mathiot, P., \& Tournadre, J. (2016). Antarctic icebergs melt over the Southern Ocean: Climatology and impact on sea ice. Ocean Modelling, 104, 99-110. https://doi.org/10.1016/j.ocemod.2016.05.001

Mitchell, B. G., \& Holm-Hansen, O. (1991). Observations of modeling of the Antartic phytoplankton crop in relation to mixing depth. Deep Sea Research Part $A$. Oceanographic Research Papers, 38(8), 981-1007. https://doi.org/10.1016/01980149(91)90093-U

Moreau, S., Lannuzel, D., Janssens, J., Arroyo, M. C., Corkill, M., Cougnon, E., et al. (2019). Sea Ice Meltwater and Circumpolar Deep Water Drive Contrasting Productivity in Three Antarctic Polynyas. Journal of Geophysical Research: Oceans. https://doi.org/10.1029/2019JC015071

Moreau, S., Mostajir, B., Bélanger, S., Schloss, I. R., Vancoppenolle, M., Demers, S., \& Ferreyra, G. A. (2015). Climate change enhances primary production in the western Antarctic Peninsula. Global Change Biology, 21(6), 2191-2205. https://doi.org/10.1111/gcb.12878

Moutier, W., Thomalla, S., Bernard, S., Wind, G., Ryan-Keogh, T., \& Smith, M. (2019). Evaluation of Chlorophyll-a and POC MODIS Aqua Products in the Southern Ocean. Remote Sensing, 11(15), 1793. https://doi.org/10.3390/rs11151793

Nicol, S., Pauly, T., Bindo, N. L., \& Strutton, P. G. (2000). "BROKE” a biological/oceanographic survey of the coast of East Antarctica (80-150E) carried out in January-March 1996. Deep Sea Research Part II: Topical Studies in Oceanography, 47(12-13), 2281-2297. 
Nihashi, S., \& Ohshima, K. I. (2015). Circumpolar Mapping of Antarctic Coastal Polynyas and Landfast Sea Ice: Relationship and Variability. Journal of Climate, 28(9), 3650-3670. https://doi.org/10.1175/JCLI-D-14-00369.1

Ohshima, K. I., Nihashi, S., \& Iwamoto, K. (2016). Global view of sea-ice production in polynyas and its linkage to dense/bottom water formation. Geoscience Letters, 3(1). https://doi.org/10.1186/s40562-016-0045-4

Paolo, F. S., Fricker, H. A., \& Padman, L. (2015). Volume loss from Antarctic ice shelves is accelerating. Science, 348(6232), 327-331. https://doi.org/10.1126/science.aaa0940

Park, J., Kuzminov, F. I., Bailleul, B., Yang, E. J., Lee, S., Falkowski, P. G., \& Gorbunov, M. Y. (2017). Light availability rather than Fe controls the magnitude of massive phytoplankton bloom in the Amundsen Sea polynyas, Antarctica. Limnology and Oceanography, 62(5), 2260-2276. https://doi.org/10.1002//no.10565

Pereira, E. S., \& Garcia, C. A. E. (2018). Evaluation of satellite-derived MODIS chlorophyll algorithms in the northern Antarctic Peninsula. Deep Sea Research Part II: Topical Studies in Oceanography, 149, 124-137. https://doi.org/10.1016/j.dsr2.2017.12.018

Périard, C., \& Pettré, P. (1993). Some aspects of the climatology of Dumont D’Urville, Adélie land, Antarctica. International Journal of Climatology, 13(3), 313-328. https://doi.org/10.1002/joc.3370130307

van de Poll, W. H., Alderkamp, A.-C., Janknegt, P. J., Roggeveld, J., \& Buma, A. G. J. (2006). Photoacclimation modulates excessive photosynthetically active and ultraviolet radiation effects in a temperate and an Antarctic marine diatom. Limnology and Oceanography, 51(3), 1239-1248. https://doi.org/10.4319/lo.2006.51.3.1239

Pritchard, H. D., Ligtenberg, S. R. M., Fricker, H. A., Vaughan, D. G., van den Broeke, M. R., \& Padman, L. (2012). Antarctic ice-sheet loss driven by basal melting of ice shelves. Nature, 484(7395), 502-505. https://doi.org/10.1038/nature10968

Racault, M.-F., Le Quéré, C., Buitenhuis, E., Sathyendranath, S., \& Platt, T. (2012). Phytoplankton phenology in the global ocean. Ecological Indicators, 14(1), 152-163. https://doi.org/10.1016/j.ecolind.2011.07.010 
Raiswell, R., Benning, L. G., Tranter, M., \& Tulaczyk, S. (2008). Bioavailable iron in the Southern Ocean: the significance of the iceberg conveyor belt. Geochemical Transactions, 9(1), 7. https://doi.org/10.1186/1467-4866-9-7

Rintoul, S. R. (1998). On the origin and influence of Adélie land bottom water. In S. S. Jacobs \& R. F. Weiss (Eds.), Antarctic Research Series (Vol. 75, pp. 151-171). Washington, D. C.: American Geophysical Union. https://doi.org/10.1029/AR075p0151

Rintoul, S. R., Silvano, A., Pena-Molino, B., van Wijk, E., Rosenberg, M., Greenbaum, J. S., \& Blankenship, D. D. (2016). Ocean heat drives rapid basal melt of the Totten Ice Shelf. Science Advances, 2(12), e1601610.

Rolinski, S., Horn, H., Petzoldt, T., \& Paul, L. (2007). Identifying cardinal dates in phytoplankton time series to enable the analysis of long-term trends. Oecologia, 153(4), 997-1008. https://doi.org/10.1007/s00442-007-0783-2

Roquet, F., Williams, G., Hindell, M. A., Harcourt, R., McMahon, C., Guinet, C., et al. (2014). A Southern Indian Ocean database of hydrographic profiles obtained with instrumented elephant seals. Scientific Data, 1(1), 140028. https://doi.org/10.1038/sdata.2014.28

Roquet, F., Wunsch, C., Forget, G., Heimbach, P., Guinet, C., Reverdin, G., et al. (2013). Estimates of the Southern Ocean general circulation improved by animal-borne instruments. Geophysical Research Letters, 40(23), 6176-6180. https://doi.org/10.1002/2013GL058304

Rysgaard, S., Nielsen, T., \& Hansen, B. (1999). Seasonal variation in nutrients, pelagic primary production and grazing in a high-Arctic coastal marine ecosystem, Young Sound, Northeast Greenland. Marine Ecology Progress Series, 179, 13-25. https://doi.org/10.3354/meps 179013

Sapiano, M. R. P., Brown, C. W., Schollaert U. S., \& Vargas, M. (2012). Establishing a global climatology of marine phytoplankton phenological characteristics. Journal of Geophysical Research: Oceans, 117(C8). https://doi.org/10.1029/2012JC007958 
Shadwick, E. H., Rintoul, S. R., Tilbrook, B., Williams, G. D., Young, N., Fraser, A. D., et al. (2013). Glacier tongue calving reduced dense water formation and enhanced carbon uptake. Geophysical Research Letters, 40(5), 904-909. https://doi.org/10.1002/grl.50178

Shadwick, E. H., Tilbrook, B., \& Currie, K. I. (2017). Late-summer biogeochemistry in the Mertz Polynya: East Antarctica. Journal of Geophysical Research: Oceans, 122(9), 73807394. https://doi.org/10.1002/2017JC013015

Shadwick, E. H., Tilbrook, B., \& Williams, G. D. (2014). Carbonate chemistry in the Mertz Polynya (East Antarctica): Biological and physical modification of dense water outflows and the export of anthropogenic $\mathrm{CO}_{2}$. Journal of Geophysical Research: Oceans, 119(1), 1-14. https://doi.org/10.1002/2013JC009286

Sharples, J., Ross, O. N., Scott, B. E., Greenstreet, S. P. R., \& Fraser, H. (2006). Inter-annual variability in the timing of stratification and the spring bloom in the North-western North Sea. Continental Shelf Research, 26(6), 733-751. https://doi.org/10.1016/j.csr.2006.01.011

Sherrell, R., Lagerström, M. E., Forsch, K. O., Stammerjohn, S. E., \& Yager, P. L. (2015). Dynamics of dissolved iron and other bioactive trace metals ( $\mathrm{Mn}, \mathrm{Ni}, \mathrm{Cu}, \mathrm{Zn})$ in the Amundsen Sea Polynya, Antarctica. Elementa, 3, 000071. https://doi.org/10.12952/journal.elementa.000071

Siegel, D. A., Doney, S. C., \& Yoder, J. A. (2002). The North Atlantic Spring Phytoplankton Bloom and Sverdrup's Critical Depth Hypothesis. Science, 296(5568), 730-733. https://doi.org/10.1126/science.1069174

Silvano, A., Rintoul, S., \& Herraiz-Borreguero, L. (2016). Ocean-Ice Shelf Interaction in East Antarctica. Oceanography, 29(4), 130-143. https://doi.org/10.5670/oceanog.2016.105 Silvano, A., Rintoul, S. R., Peña-Molino, B., \& Williams, G. D. (2017). Distribution of water masses and meltwater on the continental shelf near the Totten and Moscow University ice shelves. Journal of Geophysical Research: Oceans, 122(3), 2050-2068. https://doi.org/10.1002/2016JC012115 
Sirjacobs, D., Alvera-Azcárate, A., Barth, A., Lacroix, G., Park, Y., Nechad, B., et al. (2011). Cloud filling of ocean colour and sea surface temperature remote sensing products over the Southern North Sea by the Data Interpolating Empirical Orthogonal Functions methodology. Journal of Sea Research, 65(1), 114-130. https://doi.org/10.1016/j.seares.2010.08.002

Smyth, R. L., Akan, C., Tejada-Martínez, A., \& Neale, P. J. (2017). Quantifying phytoplankton productivity and photoinhibition in the Ross Sea Polynya with large eddy simulation of Langmuir circulation. Journal of Geophysical Research: Oceans, 122(7), 5545-5565. https://doi.org/10.1002/2017JC012747

Snow, K., Rintoul, S. R., Sloyan, B. M., \& Hogg, A. M. (2018). Change in Dense Shelf Water and Adélie Land Bottom Water Precipitated by Iceberg Calving. Geophysical Research Letters, 45(5), 2380-2387. https://doi.org/10.1002/2017GL076195

St-Laurent, P., Yager, P. L., Sherrell, R. M., Oliver, H., Dinniman, M. S., \& Stammerjohn, S. E. (2019). Modeling the Seasonal Cycle of Iron and Carbon Fluxes in the Amundsen Sea Polynya, Antarctica. Journal of Geophysical Research: Oceans, 124(3), 15441565. https://doi.org/10.1029/2018JC014773

Sverdrup, H. U. (1953). On Conditions for the Vernal Blooming of Phytoplankton. ICES Journal of Marine Science, 18(3), 287-295. https://doi.org/10.1093/icesjms/18.3.287

Tamura, T., Ohshima, K. I., \& Nihashi, S. (2008). Mapping of sea ice production for Antarctic coastal polynyas. Geophysical Research Letters, 35(7). https://doi.org/10.1029/2007GL032903

Tamura, T., Williams, G. D., Fraser, A. D., \& Ohshima, K. I. (2012). Potential regime shift in decreased sea ice production after the Mertz Glacier calving. Nature Communications, 3(1). https://doi.org/10.1038/ncomms1820

Taylor, J. R., \& Ferrari, R. (2011). Shutdown of turbulent convection as a new criterion for the onset of spring phytoplankton blooms. Limnology and Oceanography, 56(6), 22932307. https://doi.org/10.4319//o.2011.56.6.2293 
Thomalla, S. J., Fauchereau, N., Swart, S., \& Monteiro, P. M. S. (2011). Regional scale characteristics of the seasonal cycle of chlorophyll in the Southern Ocean. Biogeosciences, 8(10), 2849-2866. https://doi.org/10.5194/bg-8-2849-2011

Treasure, A., Roquet, F., Ansorge, I., Bester, M., Boehme, L., Bornemann, H., et al. (2017). Marine Mammals Exploring the Oceans Pole to Pole: A Review of the MEOP $\begin{array}{llr}\text { Consortium. } & \text { Oceanography, } & \text { 30(2), }\end{array}$ https://doi.org/10.5670/oceanog.2017.234

Tremblay, J.-É., \& Smith, W. O. (2007). Primary Production and Nutrient Dynamics in Polynyas. In Elsevier Oceanography Series (Vol. 74, pp. 239-269). Elsevier. https://doi.org/10.1016/S0422-9894(06)74008-9

Tremblay, J.-É., Michel, C., Hobson, K. A., Gosselin, M., \& Price, N. M. (2006). Bloom dynamics in early opening waters of the Arctic Ocean. Limnology and Oceanography, 51(2), 900-912. https://doi.org/10.4319/lo.2006.51.2.0900

Vaillancourt, R. D., Sambrotto, R. N., Green, S., \& Matsuda, A. (2003). Phytoplankton biomass and photosynthetic competency in the summertime Mertz Glacier Region of East Antarctica. Deep Sea Research Part II: Topical Studies in Oceanography, 50(8-9), 1415-1440. https://doi.org/10.1016/S0967-0645(03)00077-8

Villafañe, V. E., Janknegt, P. J., de Graaff, M., Visser, R. J. W., van de Poll, W. H., Buma, A. G. J., \& Walter Helbling, E. (2008). UVR-induced photoinhibition of summer marine phytoplankton communities from Patagonia. Marine Biology, 154(6), 1021-1029. https://doi.org/10.1007/s00227-008-0993-0

Wang, M. (2003). Light scattering from the spherical-shell atmosphere: Earth curvature effects measured by SeaWiFS. Eos, Transactions American Geophysical Union, 84(48), 529. https://doi.org/10.1029/2003E0480003

White, M. A., de Beurs, K. M., Didan, K., Inouye, D. W., Richardson, A. D., Jensen, O. P., et al. (2009). Intercomparison, interpretation, and assessment of spring phenology in North America estimated from remote sensing for 1982-2006. Global Change Biology, 15(10), 2335-2359. https://doi.org/10.1111/j.1365-2486.2009.01910.x 
Williams, G. D., \& Bindoff, N. L. (2003). Wintertime oceanography of the Adélie Depression. Deep Sea Research Part II: Topical Studies in Oceanography, 50(8), 1373-1392. https://doi.org/10.1016/S0967-0645(03)00074-2

Wouters, B., Martin-Español, A., Helm, V., Flament, T., Wessem, J. M. van, Ligtenberg, S. R. M., et al. (2015). Dynamic thinning of glaciers on the Southern Antarctic Peninsula. Science, 348(6237), 899-903. https://doi.org/10.1126/science.aaa5727

Yang, E. J., Lee, Y., \& Lee, S. (2019). Trophic interactions of micro- and mesozooplankton in the Amundsen Sea polynya and adjacent sea ice zone during austral late summer. $\begin{array}{llll}\text { Progress in } \quad \text { Oceanography, } & 117-130 .\end{array}$ https://doi.org/10.1016/j.pocean.2018.12.003

Young, N., Legresy, B., Coleman, R., \& Massom, R. (2010). Mertz Glacier tongue unhinged by giant iceberg. Australian Antarctic Magazine, (18), 1.

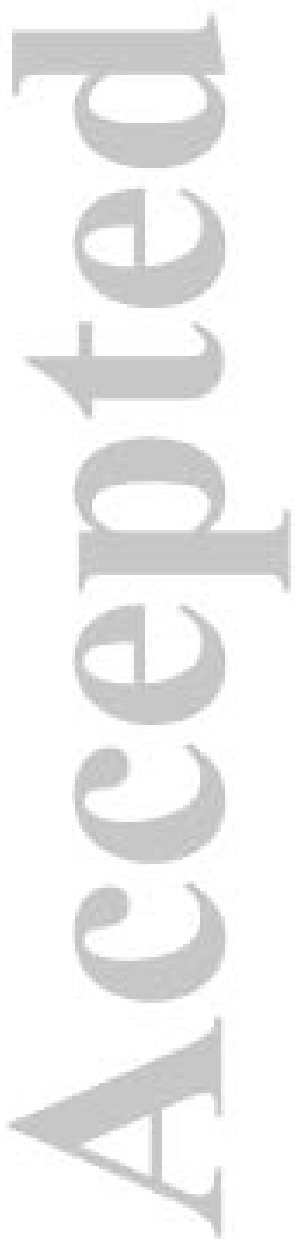


Table 1: Differences in satellite-derived Southern Ocean chl-a concentration $\left(\mathrm{mg} \mathrm{m}^{-3}\right)$ from MODIS and SeaWiFS (MODIS minus SeaWiFS), corrected for the Southern Ocean using the Johnson et al. (2013) algorithm for four arbitrary time periods, during the Austral summer: 916 Jan 2005, 9-16 Jan 2006, 9-16 Jan 2007 and 9-16 Jan 2009.

\begin{tabular}{ccccc}
\hline & $9-16$ Jan 2005 & $9-16$ Jan 2006 & $9-16$ Jan 2007 & $9-16$ Jan 2009 \\
\hline Mean difference & -0.045 & -0.048 & -0.032 & -0.057 \\
\hline Median difference & -0.047 & -0.031 & -0.027 & -0.041 \\
\hline Max difference & 29.7 & 20.74 & 18.55 & 23.41 \\
\hline Min difference & -18.39 & -20.73 & -20.84 & -17.93 \\
\hline Standard error & $3.58 \mathrm{e}-04$ & $3.36 \mathrm{e}-04$ & $3.79 \mathrm{e}-04$ & $3.54 \mathrm{e}-04$ \\
\hline Standard deviation & 0.58 & 0.54 & 0.61 & 0.57 \\
\hline
\end{tabular}

Table 2. Methods used to best determine the bloom metrics

\begin{tabular}{ll}
\hline Method & Threshold value \\
\hline Siegel et al. (2002) & Chl-a median for the entire time series $+5 \%$ \\
Marchese et al. (2017) & $20 \%$ of maximum chl-a value \\
Henson et al. (2018) & Min chl-a value $+[0.05 \times($ max chl- $a-$ min chl-a) $]$
\end{tabular}


Table 3. Average phenological bloom metrics and their associated standard deviation (SD) determined using Marchese et al. (2017) method.

\begin{tabular}{|c|c|c|c|c|c|c|c|c|}
\hline \multirow[t]{2}{*}{ Year } & \multicolumn{2}{|c|}{ Bloom start } & \multicolumn{2}{|c|}{ Peak time } & \multicolumn{2}{|c|}{ Bloom duration } & \multicolumn{2}{|c|}{ Bloom amplitude } \\
\hline & $\begin{array}{c}\text { Day } \\
\text { (Calendar) }\end{array}$ & SD & $\begin{array}{c}\text { Day } \\
\text { (Calendar) }\end{array}$ & SD & $\begin{array}{c}\text { Day } \\
\text { (Calendar) }\end{array}$ & SD & $\mathrm{mg} \mathrm{m}^{-3}$ & $\mathrm{SD}$ \\
\hline 1998 & 345 & 33 & 360 & 26 & 67 & 37 & 0.81 & 0.87 \\
\hline 1999 & 340 & 17 & 358 & 20 & 62 & 34 & 3.56 & 1.93 \\
\hline 2000 & 330 & 13 & 7 & 25 & 77 & 25 & 3.29 & 2.43 \\
\hline 2001 & 331 & 19 & 354 & 25 & 65 & 38 & 1.32 & 1.09 \\
\hline 2002 & 346 & 18 & 11 & 24 & 77 & 28 & 4.21 & 2.50 \\
\hline 2003 & 325 & 25 & 1 & 32 & 91 & 31 & 1.15 & 1.25 \\
\hline 2004 & 340 & 27 & 14 & 30 & 80 & 33 & 0.98 & 1.03 \\
\hline 2005 & 346 & 22 & 10 & 21 & 77 & 30 & 3.43 & 2.24 \\
\hline 2006 & 340 & 24 & 21 & 31 & 81 & 27 & 2.12 & 1.41 \\
\hline 2007 & 351 & 21 & 27 & 25 & 68 & 25 & 2.95 & 1.66 \\
\hline 2008 & 344 & 19 & 10 & 22 & 78 & 26 & 2.54 & 2.00 \\
\hline 2009 & 348 & 21 & 12 & 29 & 68 & 31 & 4.16 & 2.32 \\
\hline 2010 & 336 & 18 & 1 & 22 & 79 & 31 & 2.62 & 2.09 \\
\hline 2011 & 363 & 23 & 35 & 26 & 56 & 27 & 3.80 & 2.56 \\
\hline 2012 & 11 & 27 & 23 & 20 & 33 & 23 & 2.33 & 2.46 \\
\hline 2013 & 14 & 36 & 21 & 24 & 28 & 27 & 1.30 & 2.04 \\
\hline 2014 & 1 & 25 & 22 & 32 & 34 & 28 & 1.39 & 1.48 \\
\hline 2015 & 353 & 35 & 15 & 25 & 59 & 27 & 4.45 & 3.53 \\
\hline 2016 & 7 & 21 & 30 & 15 & 46 & 23 & 5.00 & 3.76 \\
\hline 2017 & 364 & 35 & 18 & 26 & 37 & 28 & 2.49 & 2.80 \\
\hline 2018 & 345 & 27 & 3 & 32 & 17 & 32 & 2.03 & 1.97 \\
\hline
\end{tabular}


Table 4. Bloom phenological parameters during pre- and post- calving periods for the whole polynya time based on our bloom and sea-ice phenology criterion. Data were averaged across the years (1998-2010 for pre-, 2010-2018 for post-calving). The p-value indicates if the trend pre- and post-calving for every parameter is significant. Significant difference $(P$-value $<0.05)$ between pre- and post-calving periods are marked by *.

\begin{tabular}{|c|c|c|c|c|c|c|c|c|c|}
\hline \multirow{2}{*}{\multicolumn{2}{|c|}{ Parameters }} & \multicolumn{4}{|c|}{ Pre-Calving } & \multicolumn{4}{|c|}{ Post-Calving } \\
\hline & & Mean & SD & Tau & $p$-value & Mean & SD & Tau & $p$-value \\
\hline \multirow{4}{*}{$\begin{array}{l}\text { Bloom } \\
\text { metrics }\end{array}$} & BS (day of year) & 342 * & 7.00 & 0.15 & 0.50 & 365 * & 11.4 & 0.06 & 0.96 \\
\hline & BD (days) & $74.7^{*}$ & 8.3 & 0.26 & 0.25 & 38.5 * & 15.2 & -0.33 & 0.25 \\
\hline & $\mathrm{BA}\left(\mathrm{mg} \mathrm{m}^{-3}\right)$ & 2.55 & 1.19 & 0.13 & 0.58 & 2.85 & 0.75 & 0.02 & 0.97 \\
\hline & $\mathrm{BM}\left(\mathrm{mg} \mathrm{m}^{-3}\right)$ & 1.53 & 0.70 & 0.13 & 0.58 & 1.93 & 0.92 & 0.11 & 0.75 \\
\hline \multirow{3}{*}{$\begin{array}{l}\text { Sea-ice } \\
\text { metrics }\end{array}$} & IRT (day of year) & 325 * & 3.90 & 0.26 & 0.25 & $345^{*}$ & 16.3 & 0.28 & 0.35 \\
\hline & OWP (days) & 108 * & 7.70 & -0.13 & 0.58 & 81.6 * & 19.4 & -0.38 & 0.18 \\
\hline & $\operatorname{SIC}(\%)$ & 10.65 * & 2.64 & 0.21 & 0.36 & 15.83 * & 5.77 & 0.22 & 0.47 \\
\hline Wind & $W S\left(m^{-2} s^{-1}\right)$ & 6.83 & 0.82 & -0.10 & 0.67 & 6.85 & 0.83 & -0.44 & 0.12 \\
\hline SST & SST $\left({ }^{\circ} \mathrm{C}\right)$ & -0.30 & 0.36 & 0.21 & 0.54 & -0.55 & 0.13 & -0.21 & 0.54 \\
\hline
\end{tabular}


Table 5. Regional comparison of phenological parameters for pre- (1998-2010) and postcalving (2010-2018) time period. Data show mean \pm std for each region. Significant difference $(P$-value $<0.05)$ between east and west for both periods are marked by *. Significant difference

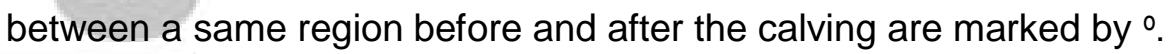

\begin{tabular}{|c|c|c|c|c|}
\hline & \multicolumn{2}{|c|}{ Pre-calving } & \multicolumn{2}{|c|}{ Post-Calving } \\
\hline & West & East & West & East \\
\hline BS (day of year) & 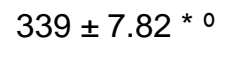 & $351 \pm 8.44$ * & $2.00 \pm 11.8^{\circ}$ & $361 \pm 13.5$ \\
\hline BD (days) & $85.0 \pm 8.8$ * ㅇ & $57.2 \pm 12.35^{*}$ & $43.9 \pm 16.27^{\circ}$ & $46.9 \pm 13.72$ \\
\hline $\mathrm{BM}\left(\mathrm{mg} \mathrm{m}^{-3}\right)$ & $1.31 \pm 0.70$ & 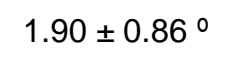 & $1.37 \pm 0.87$ * & $2.60 \pm 1.09 * 0$ \\
\hline $\mathrm{BA}\left(\mathrm{mg} \mathrm{m}^{-3}\right)$ & $2.31 \pm 1.12$ & 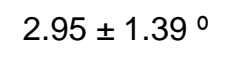 & $2.00 \pm 1.34$ * & $3.96 \pm 1.63 * 0$ \\
\hline SIC (\%) & $7.63 \pm 10.2$ * $\varrho$ & $14.7 \pm 3.48^{*}$ & $17.0 \pm 6.6^{\circ}$ & $14.97 \pm 6.07$ \\
\hline SST $\left({ }^{\circ} \mathrm{C}\right)$ & $-0.27 \pm 0.43$ & $-0.35 \pm 0.27$ & $-0.63 \pm 0.16$ & $-0.49 \pm 0.18$ \\
\hline PAR (Einstein $\mathrm{m}^{-2} \mathrm{~d}^{-1}$ ) & $37.4 \pm 1.99$ & $36.4 \pm 4.05$ & $27.0 \pm 5.18$ & $27.7 \pm 3.07$ \\
\hline
\end{tabular}




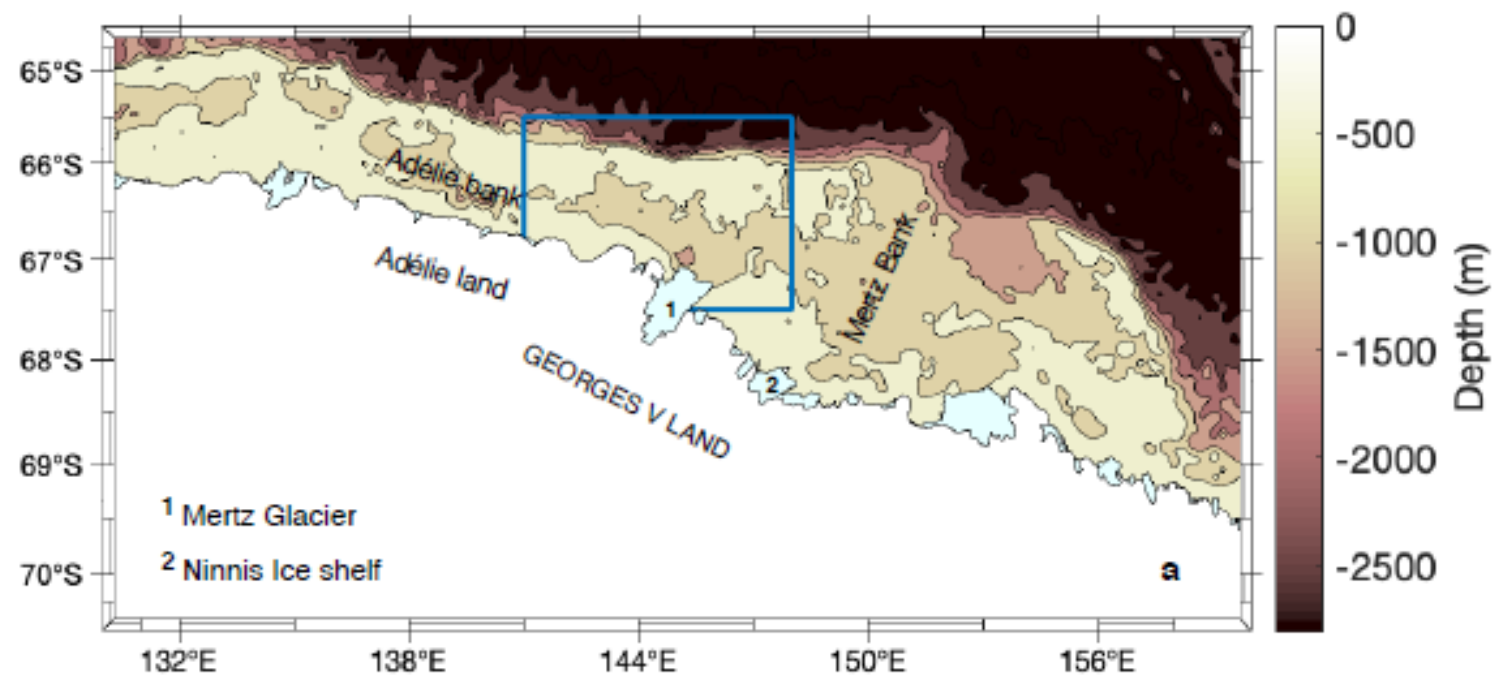

竞

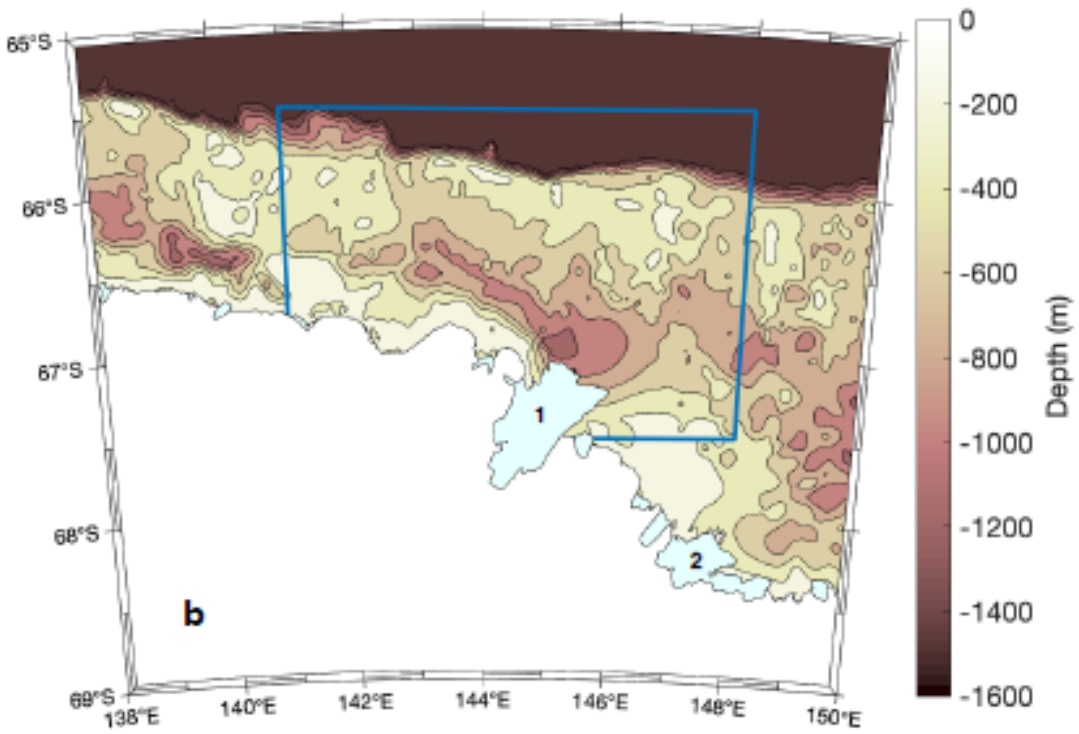

\section{Longitude}

Figure 1. Map of the study zone, including the Mertz polynya (blue box). The bathymetry is from ETOPO1 (http://www.ngdc.noaa.gov/mgg/global/global.html). The area in white is mainland Antarctica. Light blue areas indicate floating ice shelves and glaciers. The Mertz Glacier tongue is represented as it was after the calving. Major bathymetric features shown include the Mertz bank in the east and the Adelie bank in the western part of the study area. 

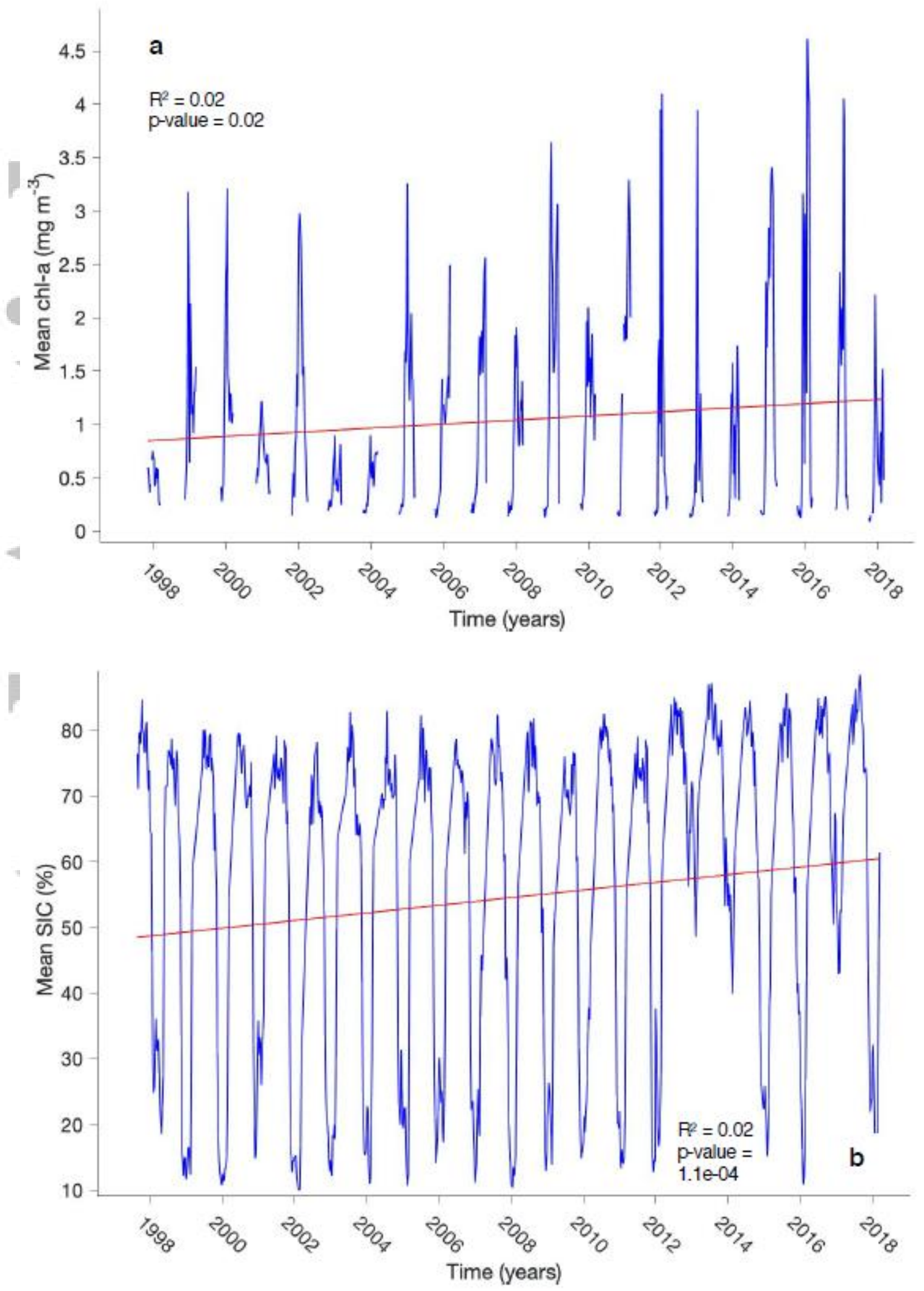

Figure 2. (a) Chl- $a(n=399)$ and (b) sea-ice concentration $(n=756)$ time series from 8 days data averaged over the study area from September 1997 to December 2018. The whole merged datasets, regardless of the bloom period, were used to calculate these time series. 


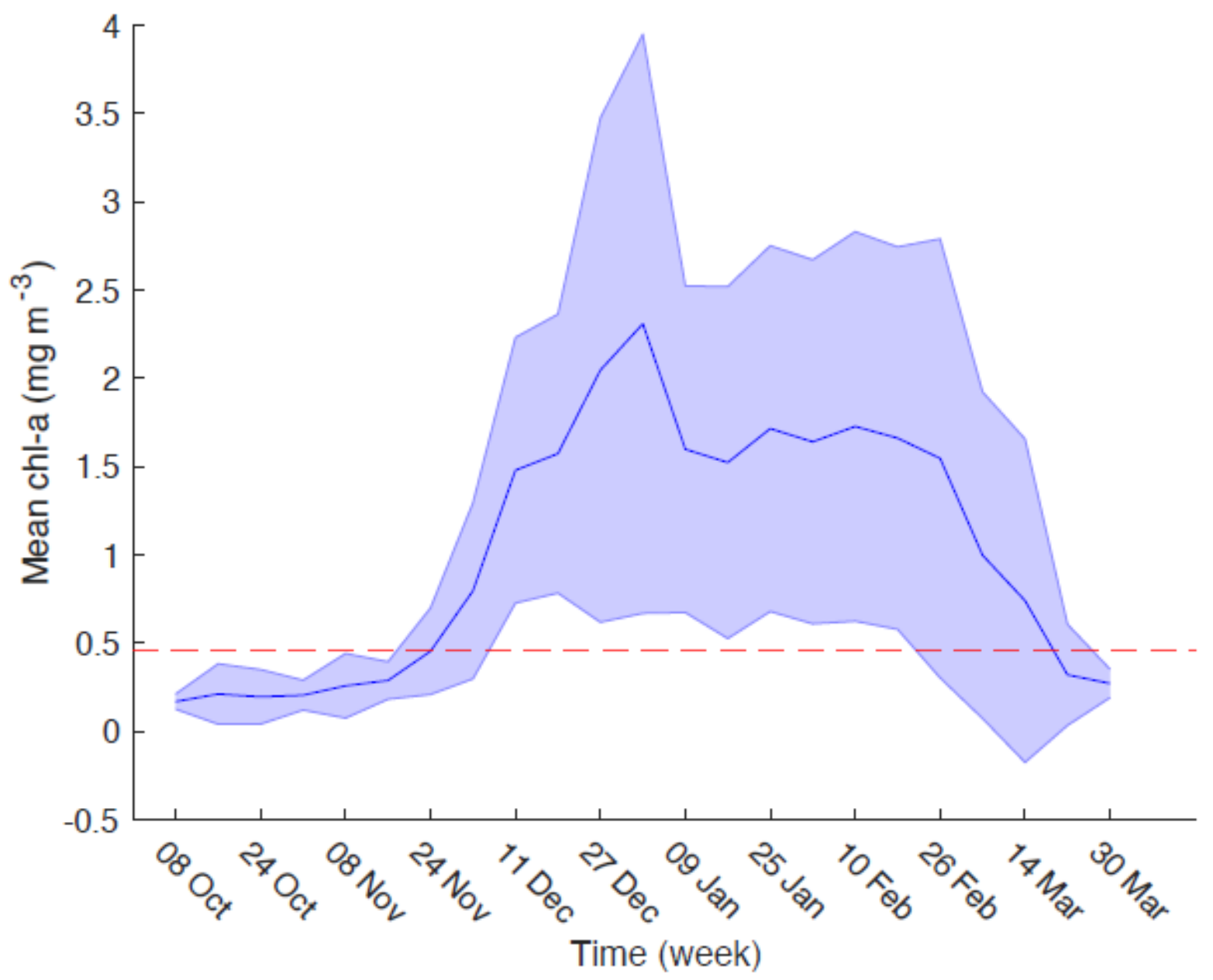

Figure 3. Annual climatology of chl-a for the time period 1997-2018 ( $n=21$ for each 8day period). Graph shows mean (blue curve) \pm standard error (blue shaded area). The dashed red line represents the bloom threshold determined for this annual chl-a climatology with the Marchese et al. (2017) method. The increased standard error during the highest chl-a concentrations is caused by an increase in the standard deviation of the mean (supplementary Figure S4). 

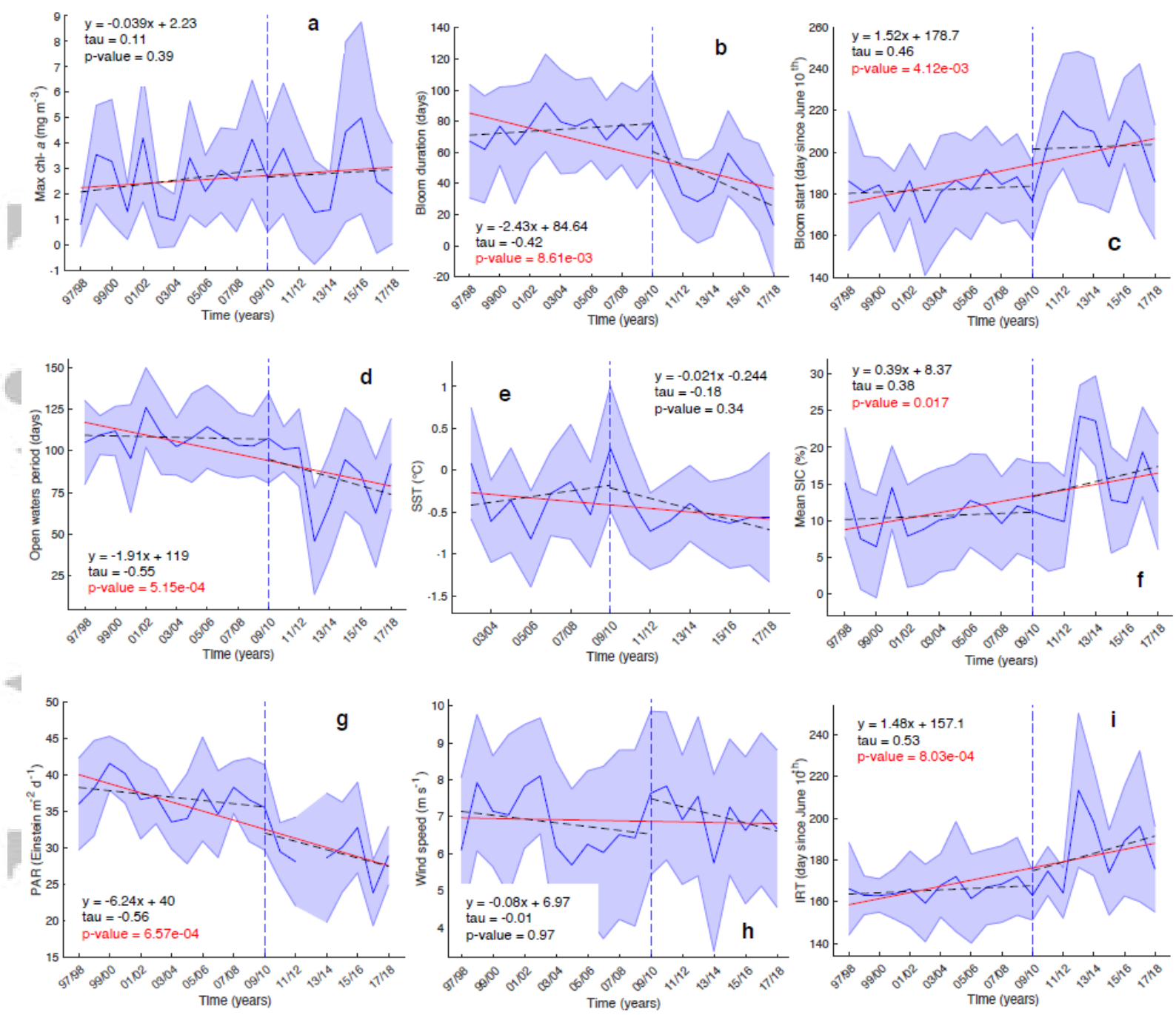

Figure 4. Times series of the main bloom metrics (bloom amplitude (a), bloom duration (b), and bloom start (c), using Marchese et al. (2017) method) and of environmental factors (open water period (d), sea surface temperature (e), sea-ice concentration (f), photosynthetically active radiation (g), wind speed (h) and ice-retreat time (i)) averaged for the study area for the bloom period. The solid blue line is the annual mean \pm standard deviation (shaded blue). The red line is the linear trend for the 21 years time series (16 for SST). The two black dashed lines are the linear trend before and after the calving, separated by the blue dashed line marking the calving year. Equation, $R^{2}$ and $p$-value are shown for each parameter. 

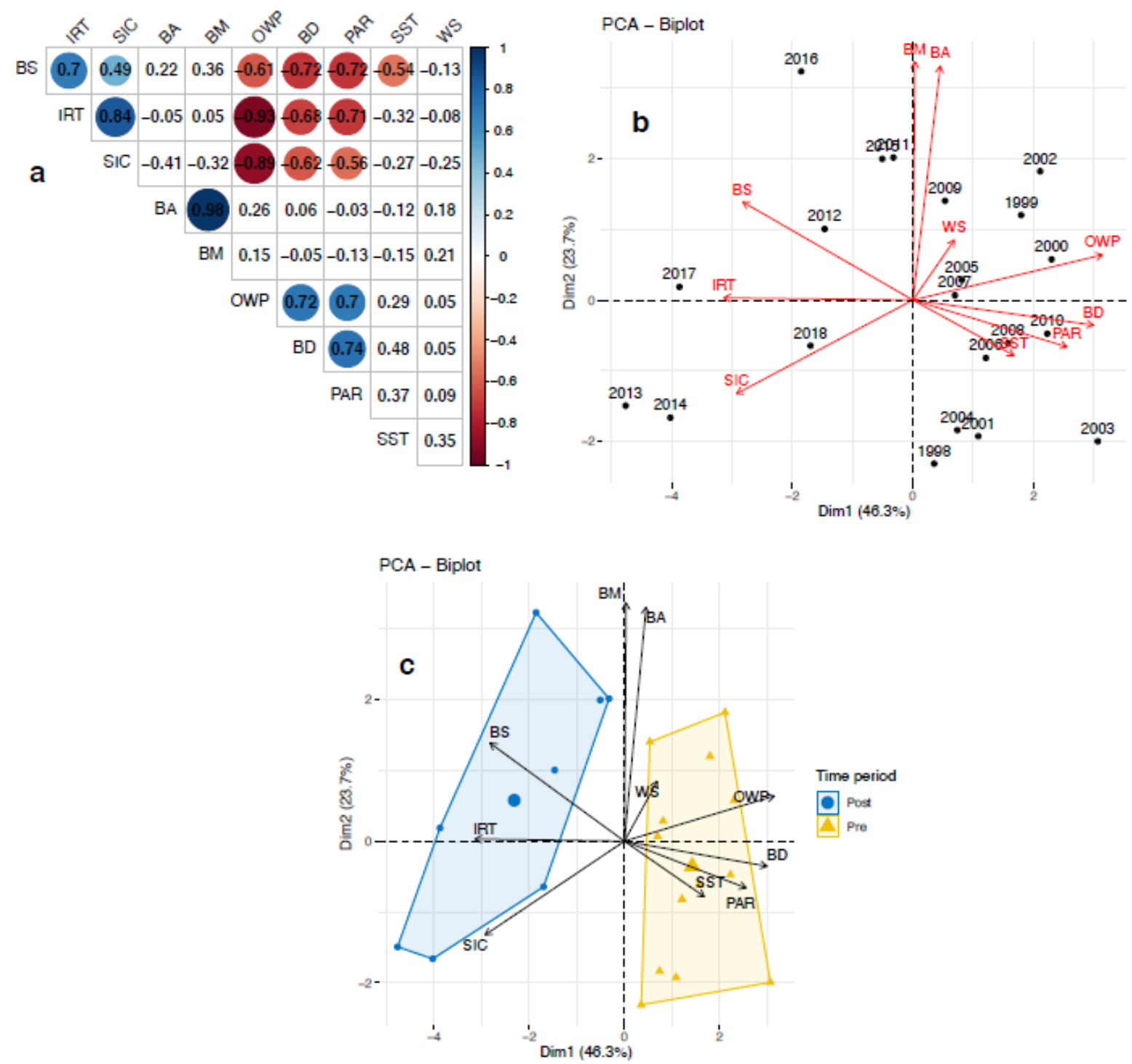

Figure 5. (a): Spearman's rank correlation $(\rho)$ matrix between bloom metrics and environmental factors: BS (bloom start), IRT (ice-retreat timing), SIC (sea-ice concentration), BA (bloom amplitude), BM (mean chl-a concentration), OWP (openwater period), BD (bloom duration), PAR (photosynthetically active radiation), SST (sea surface temperature) and WS (wind speed). Red indicates a significant $(p<0.05)$ negative correlation, while the blue indicates a significant $(p<0.05)$ positive correlation. No color means no significant correlation. The size of the circle represents the strength of the correlation. The color bar (from red to blue) indicates the magnitude of the correlation. White is used when the correlation between indicators is not significant $(p$ $>0.05$ ) according to the Spearman correlation statistical test. (b) Principal component analysis biplot of: variables (red arrows) and years (1997-2018) represented by the black dots. (c) Principal component analysis biplot of: variables (red arrows) and years (colors). Pre-calving years (1998-2010) are yellow filled triangles, post-calving (20112018) are blue filled circles. The largest blue filled circle and yellow filled triangle represent the center of the ellipse for the pre-calving and post-calving clusters respectively. 

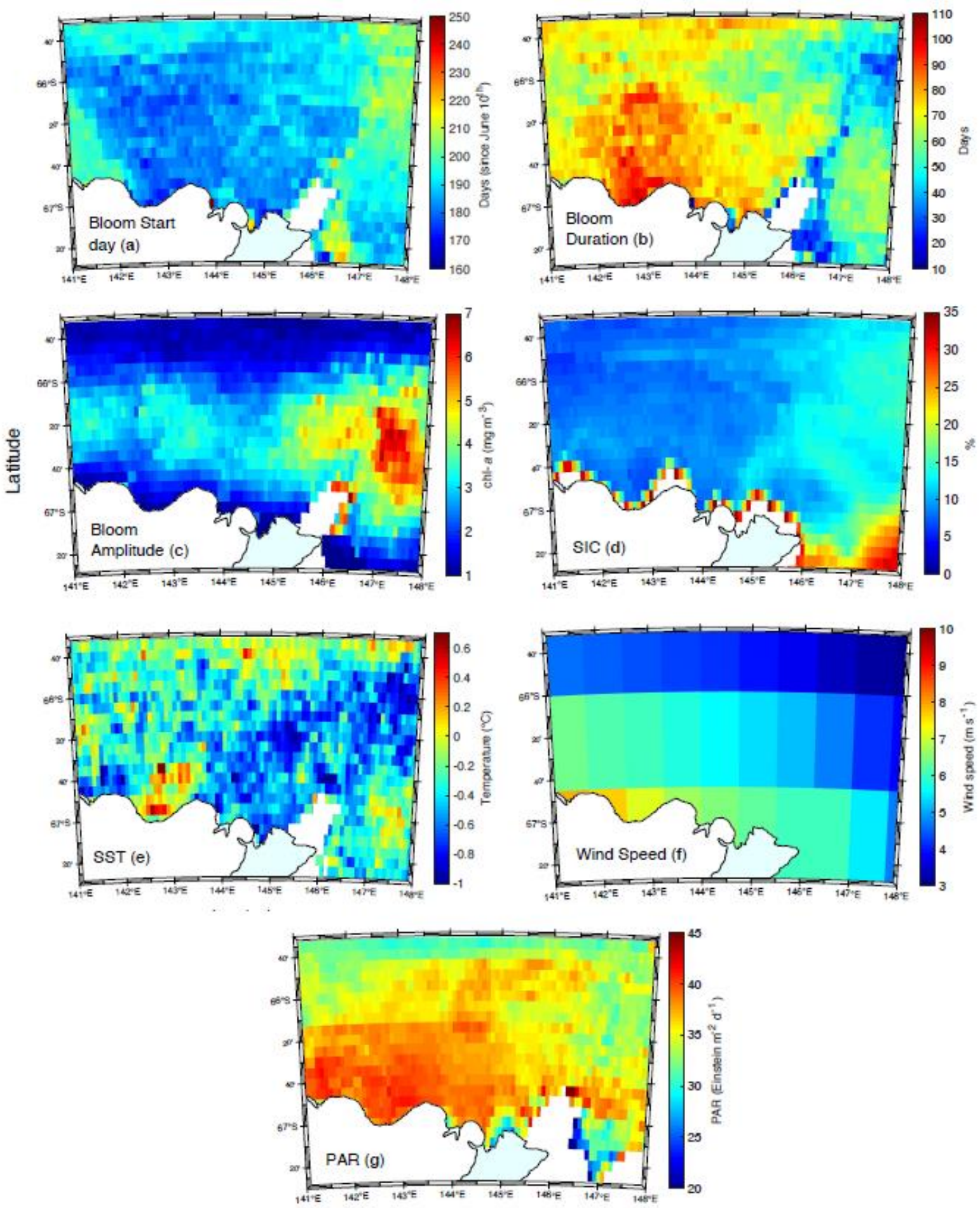

Longitude

Figure 6. Annual climatology (1997-2018) of bloom start (a), bloom duration (b), bloom amplitude (c), sea-ice concentration (d), sea surface temperature (2002-2018, e), wind speed (f) and photosynthetically active radiation (g). The coastline is represented in white with thin black contour. The light blue part shows the new ice shelf after the calving. The white part with no contour represents missing data due to the presence of the old Mertz Glacier Tongue. 

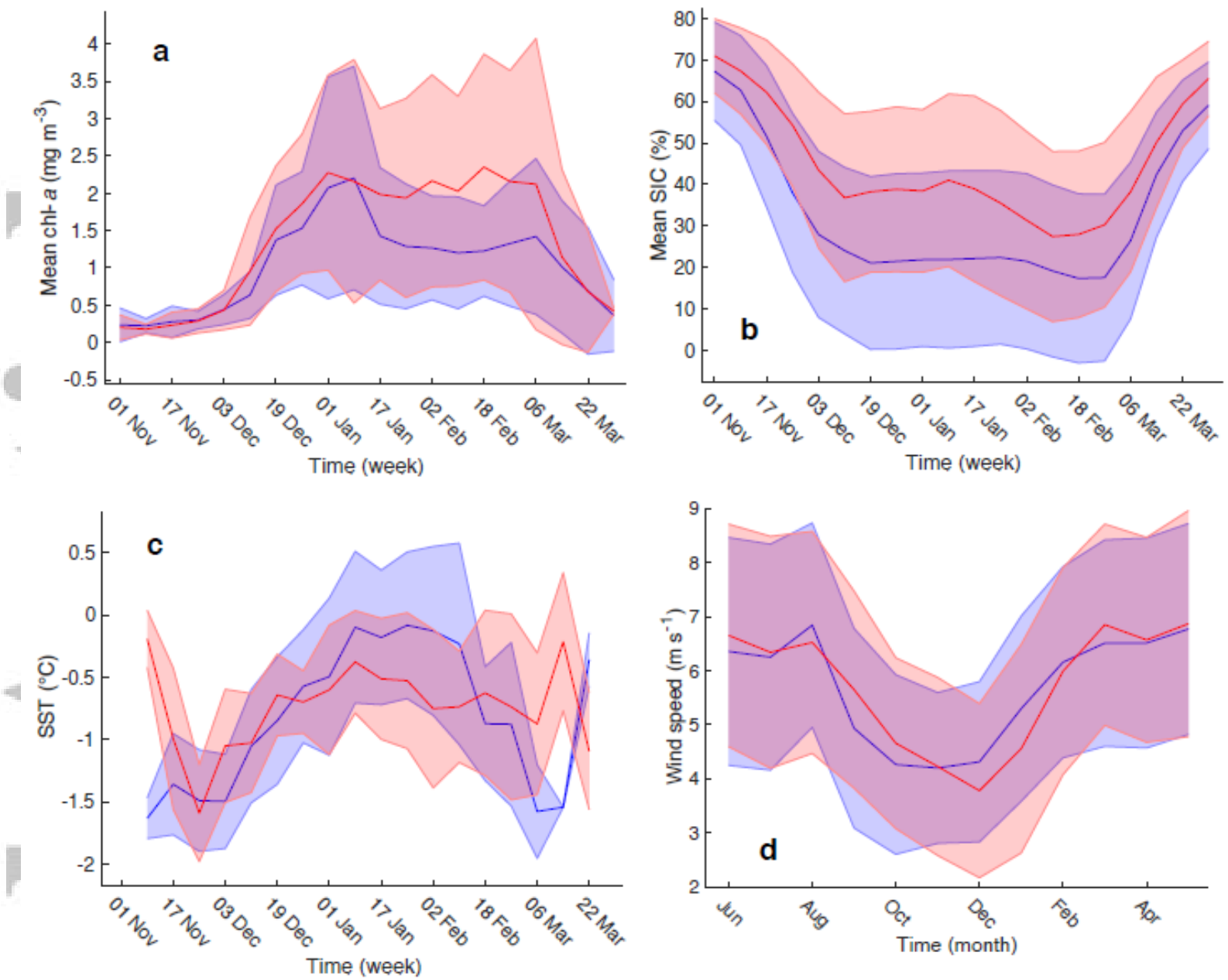

Pre Calving 1997 - Fөb 2010

Post Calving Feb 2010 - 2018

Figure 7. 8-day data climatology pre- and post-calving for mean chl-a concentration (a), mean sea-ice concentration (b), mean sea surface temperature (c) and mean wind speed (d). Graph shows mean (thick line) \pm standard deviation (shaded area). Blue color represents the pre-calving period (1997 - February 2010) while red represents the post-calving (February 2010 - December 2018). The whole datasets, regardless of the bloom period, were used to calculate these time series. 

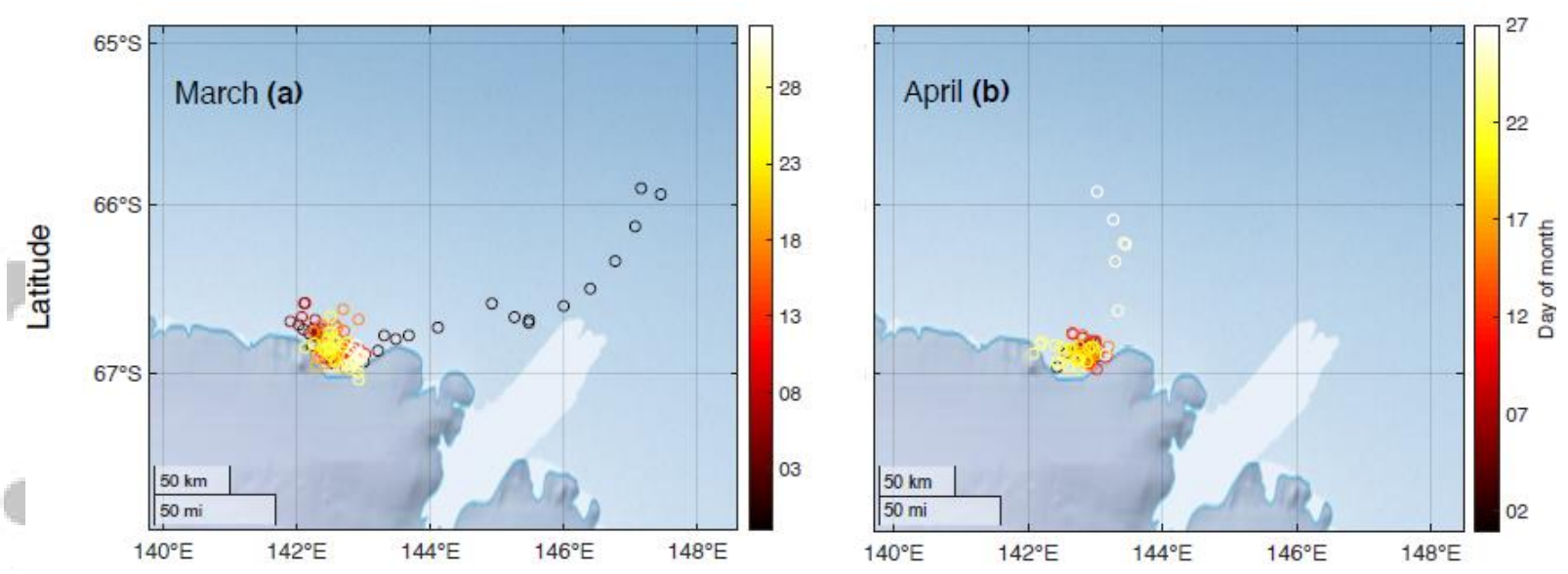

Longitude

Figure 8. Elephant seal dives in the Mertz polynya from end of February to end of March (a) and all April (b) in 2009. Dark color in figure (a) shows the last day of February and beginning of March. The white part shows the Mertz glacier tongue prior to the calving for both figures.

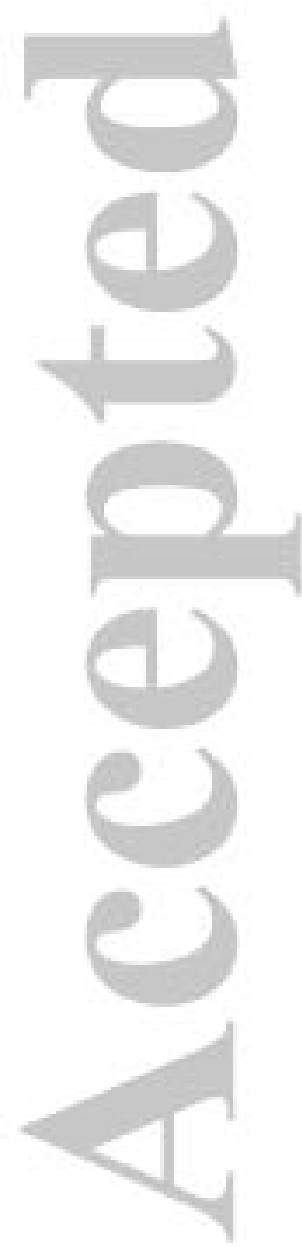



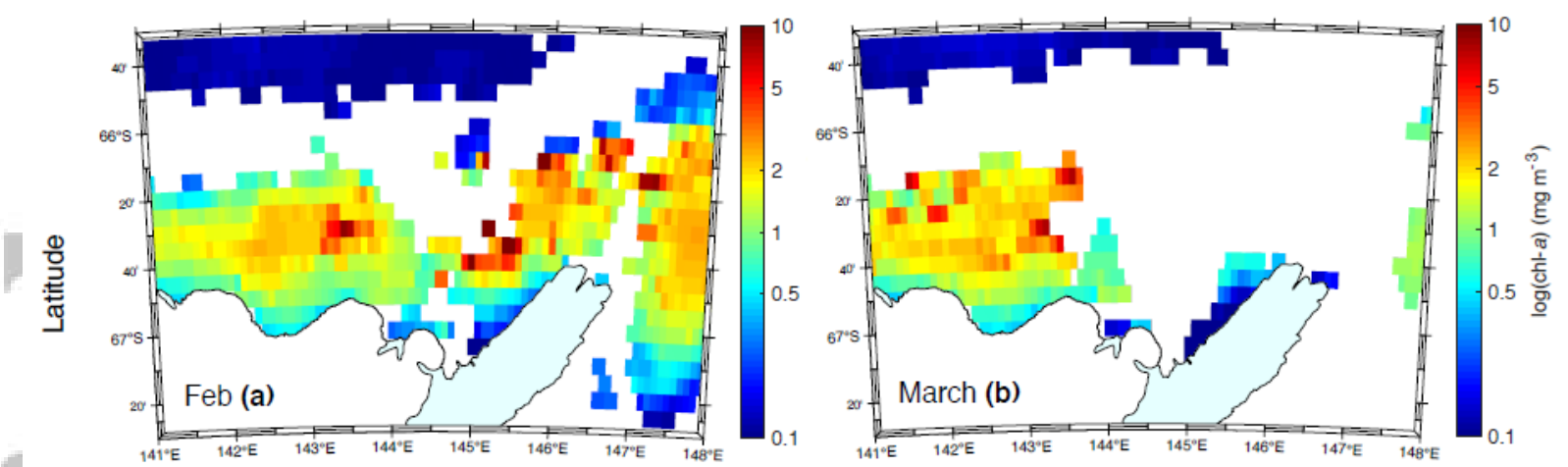

Longitude

Figure 9. (a) Average daily chl-a data available for this seal for February $(n=7)$ and (b) March $(n=31)$ when the SES was in the Mertz polynya. The coastline is represented in white with thin black contour. The light blue part is the Mertz Glacier Tongue prior to the calving.

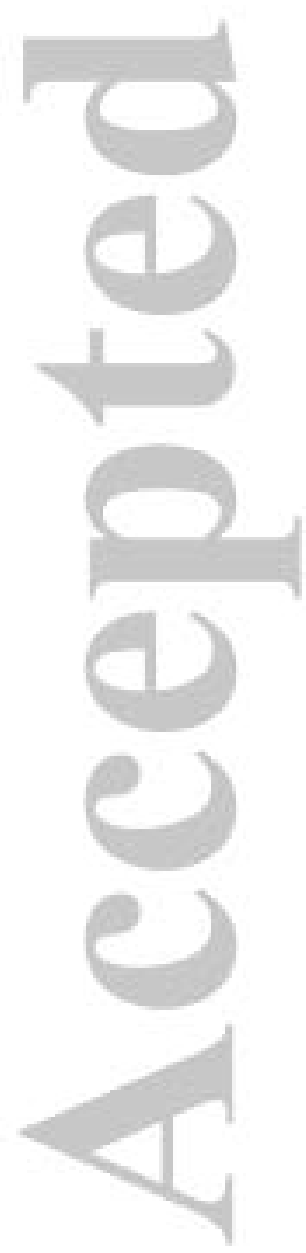

